\title{
동해안 주요 해빈의 해빈폭과 파랑의 상관성 분석 Correlation Analysis between Beach Width and Wave Data on the East Coast of South Korea
}

\author{
오정은* · 정원무*·김기현** . 강태순** \\ Jung-Eun Oh*, Weon-Mu Jeong*, Ki-Hyun Kim** and Tae-Sun Kang**
}

요 지 : 파랑의 작용에 의해 유사가 이동되어 연안의 침식 - 퇴적이 일어나지만 상당히 비선형적이고 비정상적인 과정이므로, 파랑과 침식 · 퇴적의 상관성을 밝히고 예측하기는 쉽지 않다. 본 연구는 동해안에서 비디오 모니터링으 로 얻은 5 개 지점의 해빈폭 자료와 인근의 3 개 지점의 파랑 모니터링 자료를 연계하여 상관성을 분석하였다. 전체 자료에 대한 상관분석에서는 유의미한 상관성이 없었지만, 기간 및 파랑 조건에 따른 상관분석에서는 주목할 만한 결과들이 제시되었다. 파고의 비초과확률이 약 $99 \%$ 이상인 경우에는 주기와 해빈폭 변화 사이에 강한 음의 상관성 이 있었으며, 주기의 비초과확률이 약 $99 \%$ 이상인 경우에는 파고와 해빈폭 변화 사이에 강한 음의 상관성이 있었다. 주파향이 해안선 직각 방향과 인접한 경우, 주파향으로 입사하는 파랑에 대해 해빈폭이 확연히 감소하였다. 해빈폭 과 파랑 사이에 뚜렷한 계절적 상관성이 나타나지는 않았으나, 태풍과 같은 특정 사건의 영향을 크게 받는 것으로 나타났다. 이러한 연구 결과의 실제 현장 적용을 위해서는 이와 같은 조건에 따른 상관 분석을 상세히 하여 해빈폭 변화 경향의 기준이 되는 파랑에 대해 더욱 정확한 정보를 얻을 필요가 있다.

핵심용어 : 파랑 모니터링, 비디오 모니터링, 해빈폭, 상관계수, 동해안

\begin{abstract}
Ocean waves are the driving force for the sediment transport and the beach process. However, wave actions are nonlinear and non-stationary, and the response of the beach is inconsistent in terms of reaction rate and magnitude. Therefore, the beach process is difficult to predict accurately. The purpose of this study is to identify the correlations between the shoreline change and ocean waves observed in the east coast of Korea. The relation of the beach width obtained from video monitoring at five sandy beaches and the wave data obtained from nearby wave monitoring at three points was analyzed. Although the correlations estimated over the whole data sets was not significant, the correlations estimated based on the seasonal period or wave conditions provided more noteworthy information. When the non-exceedance probability of the wave height was greater than 0.99 , the wave period and beach width showed strong negative correlations. In case the non-exceedance probability of the wave period was greater than 0.99 , the wave height and beach width showed strong negative correlations as well. Furthermore, the erosion rate of the beach width increased when the primary wave direction was close to normal to the coastline. Little significant seasonal or monthly change was found between the beach width and the wave, but it was greatly affected by intensive events such as typhoons. Thus, it is necessary to analyze in detail the wave height or period level explaining the change of beach width for more relevant and practical information.
\end{abstract}

Keywords : wave monitoring, video monitoring, beach width, correlation coefficient, east coast

\section{1. 서 론}

해안의 상태는 끊임없이 평형화 과정을 거치고 있다 (Davidson et al., 2013). 파랑이 모래 해안 변화의 주동인(主 動因)이지만, 파랑의 작용은 매우 비선형적이고 비정상적이다. 이러한 파랑의 작용으로 모래는 물속에서 자유롭게 이동하게
되는데, 이와 같은 유사이동에 의한 해안의 변화를 정밀하게 예측하는 것은 어렵다(Cooper and Pilkey, 2004). 모래로 이 루어진 해안은 이러한 파랑장(wave field) 뿐 아니라 유사 공 급 상황에 따라서도 점진적이거나 급격하게 변한다(Uda, 2017). 이와 더불어 이전 상태의 모래 분포에 대해서도 비선 형적 의존성을 가지고 변하게 된다(Múnera et al., 2014). 이

*한국해양과학기술원 해양공학연구본부(Corresponding author: Jung-Eun Oh, Coastal and Ocean Engineering Division, Korea Institute of Ocean Science and Technology, 385, Haeyang-ro, Yeongdo-gu, Busan 49111 Korea, Tel: +82-51-664-3574, jungeunoh@kiost.ac.kr)

**(주)지오시스템리서치(GeoSystem Research Corporation) 
러한 유사이동에 의한 해안의 변화에 있어 해안선 평형 프로 파일은 개념은 가장 중요한 기본 이론이다(Burvingt et al., 2017). 이를 바탕으로 파고, 주기와 더불어 해안 바닥면에서 의 마찰과 쇄파여부, 모래의 침강속도, 흐름(current), bar 주 변에서의 변화 등 여러 관련 변수들을 탐구하고 해안선 평형 모델(shoreline equilibrium model)에 적용해 왔다(Wright and Short, 1984; Yates et al., 2009; Davidson et al., 2013). 해안의 공간적 변화는 이러한 해안선 평행 모델에서 다루는 유체역학적 힘에 기인하지만, 그 변화의 변동성은 해변 유형 및 지질역학적 특성에 따라 달라지기도 한다(Loureiro et al., 2012). 또한 폭풍 또는 겨울철 고파랑 등의 극단적 파랑 조 건에서는 해안의 변화도 상당히 큰 폭으로 생기고 이에 따라 복잡한 양태의 공간적 변화가 야기되기도 한다(Masselink et al., 2015; Scott et al., 2016).

본 논문에서는 동해 여러 해안에서의 비디오 모니터링을 기 반으로 추출한 해빈폭의 변화와 인근에서 관측된 파랑을 활 용하여 파랑에 의한 해안선 변화 양상을 연구하였다. 2003년 연안침식 모니터링 체계구축 기본계획 수립 후 우리나라 대 표 해안들에서 비디오 모니터링을 시작하였으며, 이후 관측 사이트가 증가하여 2016년에는 39 개소에 이르렀다. 이와 관 련하여 Kang et al.(2007)은 실시간 비디오 모니터링 기법으 로 우리나라 주요 해수욕장에서의 침식 현황을 분석하였으며, $\operatorname{Kim}$ and $\operatorname{Kim}(2014)$ 은 태풍 발생 시 사구의 침식특성에 대 하여 비디오 영상을 통해 파악하기도 하였다. $\operatorname{Kim}(2016)$ 은 남해안 및 제주해안에서의 백사장 침식변화를 영상자료로부 터 분석하였고, Kang et al.(2017)은 국내 대표 해수욕장인 해운대 해수욕장에서 모니터링한 영상자료로부터 해빈폭을 추 출하여 해빈의 변동특성을 분석하였다. 이와 같이 비디오 모 니터링을 통한 영상자료는 연안 침식 - 퇴적 문제를 다루는 데 유용하게 사용되어 왔으며, 기존에 유지되고 있는 모니터 링으로부터 추출한 자료를 활용하는 것은 현장관측을 수행하 는 것에 비해 매우 경제적이다.

그러나 비디오 영상으로부터는 추출한 자료는 현장관측 자 료에 비해 정확도가 떨어질 수 있으며, 이를 통해서는 모래 해안의 지상 변화만을 관찰할 수 있다는 한계가 있다. 또한 해빈폭 변화와 연계할 파랑 자료도 안정적인 자료 취득을 위 해 연안에서 다소 떨어진 지점에서 관측한 것으로서 해당 해 안에 완전히 인접한 지점에서의 파랑 자료는 아니다. 이러한 제약에도 불구하고, 우리나라 동해안 다지점의 비디오 모니 터링 자료를 사용하여 여러 파랑 조건 하에서 해빈폭 변화 경 향을 살펴보는 것은 동해안의 해안 변화 특성을 이해하는데 중요한 기본 정보를 줄 것으로 기대된다. 더불어 동해 연안 에서의 계절성과 지형적 특성이 파랑과 더불어 해안 발달에 어떤 영향을 미치는지 확인할 수 있을 것이다. 향후 해안선 평형 모델 및 자료 기반 모델 등을 동해안에 적용할 때 이 러한 정보를 활용한다면, 모델을 통해 보다 합리적인 결과를 도출하는 데 도움이 될 수 있을 것이다.

\section{2. 파랑 및 해빈폭 자료 처리}

해변의 침식 · 퇴적 양상을 반영하는 해빈폭의 변화와 파 랑 인자 사이의 상관관계를 검토하기 위해, 비디오 모니터링 에서 추출한 해빈폭 자료와 파랑 모니터링 자료를 상호 연계 하여 분석하였다. 파랑 모니터링 자료로는 해양수산부에서 운 영하는 공현진, 맹방해수욕장, 후포항 세 정점의 자료를 활용 하였다(Ministry of Oceans and Fisheries, 2018). Fig. 1의 지도에 각 관측점 위치가 원으로 표시되어 있으며, 하단에 각 지점의 위 · 경도 및 수심 정보가 있다. 그리고 해양수산부 에서 연안침식 비디오 모니터링으로 관측하고 있는 39개소 (Ministry of Oceans and Fisheries, 2018) 중 파랑 모니터링 정점에 가까운 5 군데 해변들(Fig. 1에서 마름모 표시)을 연계 하여 추출된 해빈폭 자료에 대해 파랑 자료와의 상관성을 검 토하였다. 이에 따라 공현진은 교암 및 봉포 해변과, 맹방은 하맹방 해변과, 후포는 월송리와 고래불 해변과 연계되었다. 서 해와 남해의 비디오 모니터링 자료는 조위 변화에 따른 해빈 폭 추출의 어려움으로 인하여 본 연구대상에서는 제외되었다.

\section{1 파랑 자료}

Ministry of Oceans and Fisheries(2018)에서는 최근 연안 환경변화 및 해안 인공구조물 건설로 인하여 백사장 침식, 해 안선 후퇴 등 심각한 연안침식 피해가 발생하고 있는 점을 감 안하여 연안의 침식 · 퇴적 원인분석을 위하여 외력 중 가장 큰 영향을 주는 파랑의 특성을 조사, 분석하고 있다. 침식 · 퇴적 조사와 관계된 파랑관측은 동해 4 개소, 서해 1 개소에서 실시되고 있으나 본 연구에서는 동해 3 개소 자료를 활용하였

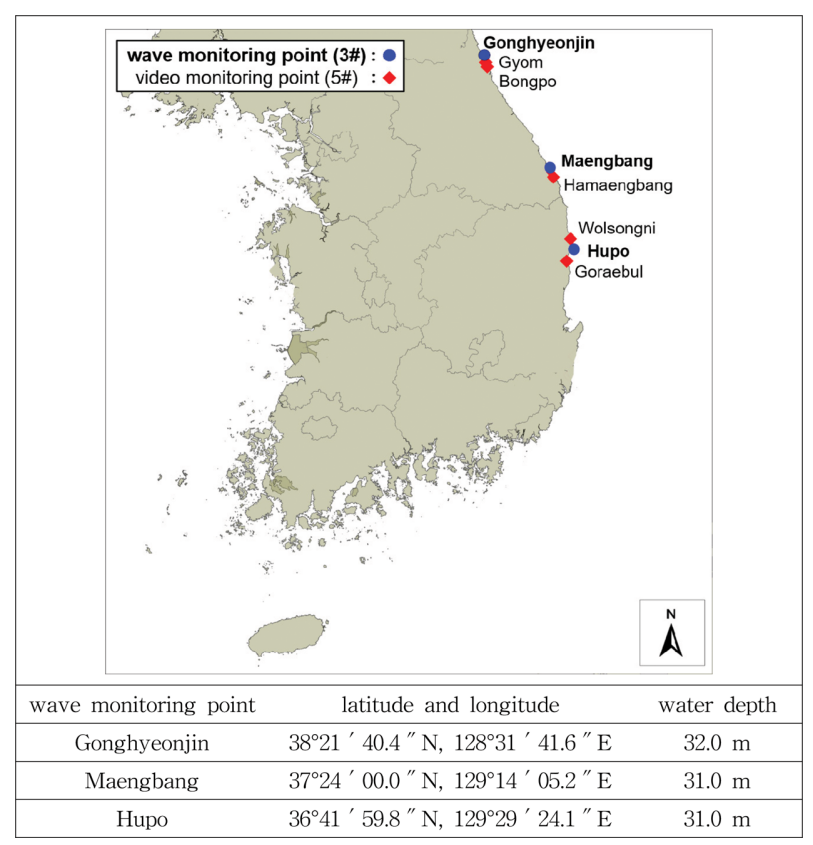

Fig. 1. Location map of the video and wave monitoring points for linkage analysis and location information of wave monitoring points. 
다. 관측기기로는 파고와 파향을 동시에 관측할 수 있는 노르 웨이 Nortek社의 초음파식 파고 · 파향계인 AWAC(Acoustic Wave And Current meter, $600 \mathrm{KHz}$ )이 사용되었다. 정확한 관측 위치, 설치수심, 관측기간 등은 Ministry of Oceans and Fisheries(2018)에 제시되어 있다.

$\mathrm{AWAC}$ 은 0.5 초마다 2,048 개의 수위 정보 등을 수집하여 기 기 내부에 저장하며, 기기를 회수하여 저장된 원시자료를 백 업한 후 제작사에서 제공하는 파랑분석 전용 소프트웨어인
Storm64를 이용하여 분석하였다. Storm64는 스펙트럼법과 파 별분석법을 모두 사용하여 파랑정보를 산출하며 매 30 분마다 유의파고 $\left(H_{m 0}\right.$ 또는 $\left.H_{1 / 3}\right)$, 첨두주기 $\left(T_{p}\right)$, 유의파주기 $\left(T_{1 / 3}\right)$, 첨두 파향 $\left(\operatorname{Dir}_{T_{p}}\right)$, 평균파향 $\left(D i r_{m n}\right)$ 등이 제시된다. 분석된 파향은 관 측기기의 특성 상 자북(Magnetic north)을 나타내며 본 연구 에서는 각 관측정점에서의 도자각(GM angle)을 빼서 도북 (Grid north)을 기준한 파향으로 보정하고 사용하였다. 이와 같 이 산출된 파랑 자료를 매 시각 자료로 리샘플링(resampling)

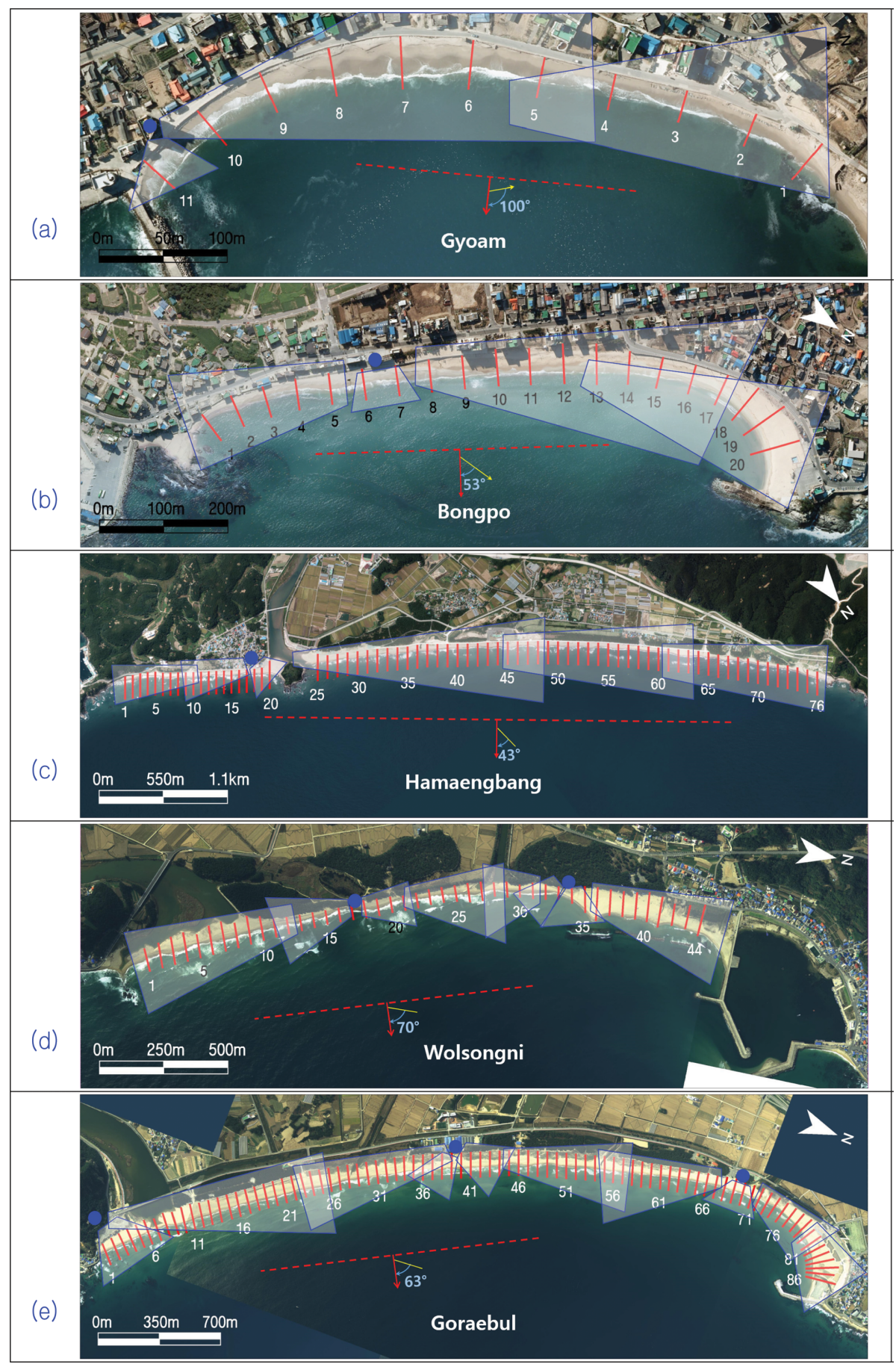

Fig. 2. Map of video monitoring beaches: contains beachlines (vertical lines), camera position $(\mathbf{O})$, and normal direction angles $\left({ }^{\circ}\right)$ to the shoreline. 


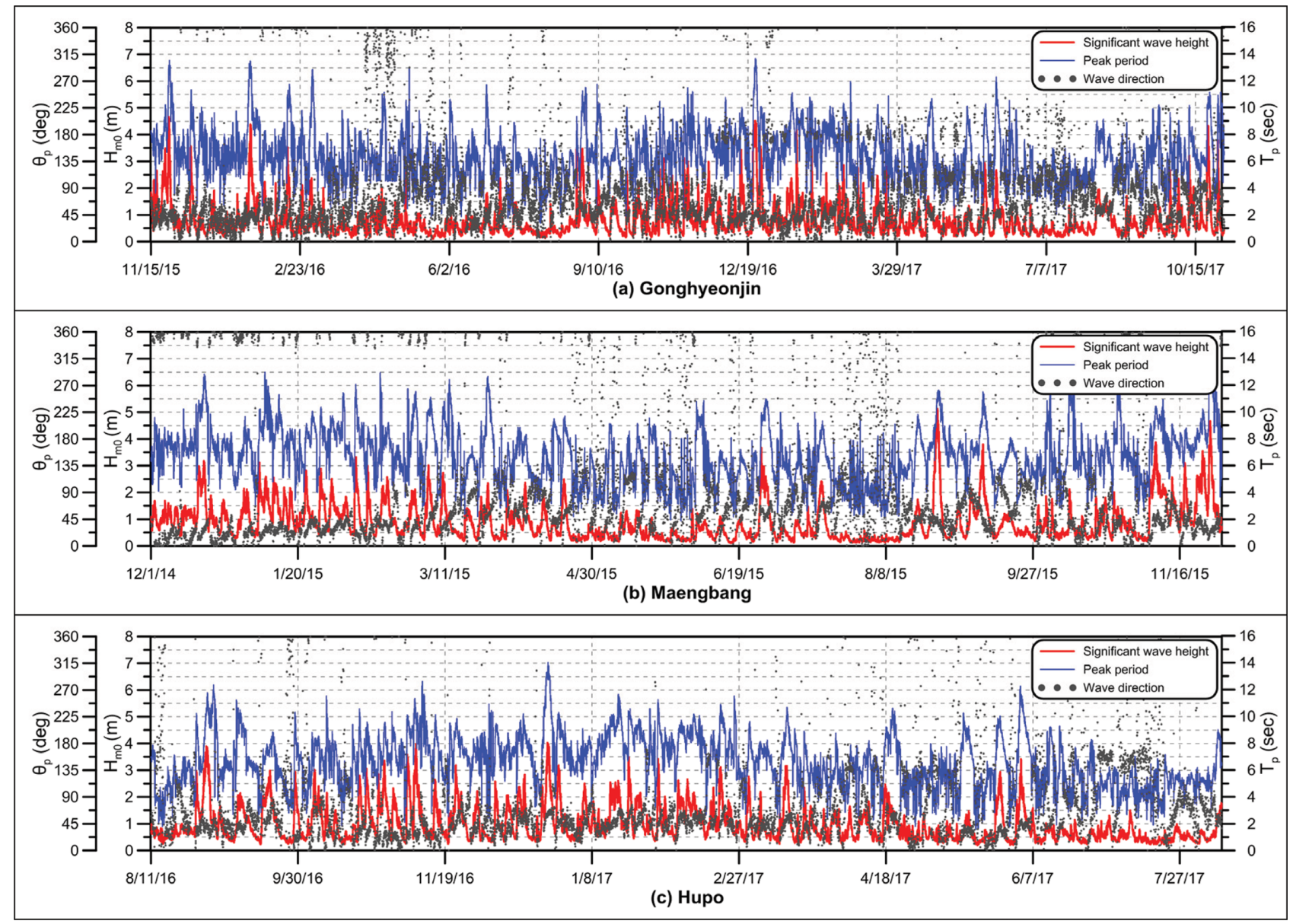

Fig. 3. Time series of significant wave height, peak period, and peak wave direction at Gonghyeonjin, Maengbang, and Hupo.

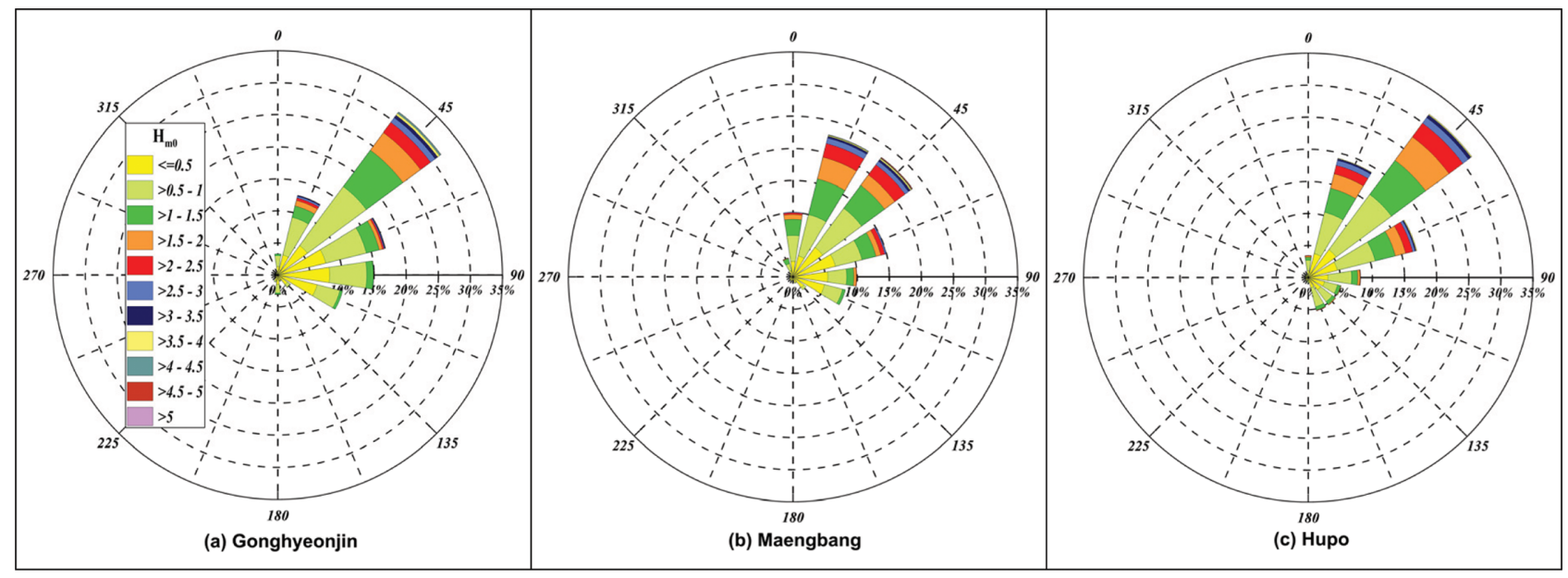

Fig. 4. Wave rose of Gonghyeonjin, Maengbang, and Hupo.

하여 분석에 사용하였다.

Fig. 3에는 본 연구의 분석에 사용된 기간에 해당되는 공 현진항의 2 년간, 맹방 해수욕장과 후포항의 1 년간의 유의파 고, 첨두주기, 첨두파향의 시계열을 도시하였다. 이 기간 동 안의 파랑 자료에 대한 자세한 정보들은 Ministry of Oceans and Fisheries $(2015,2016,2017)$ 에 제시되어 있다. 그리고
Fig. 4에는 동일한 기간(공현진항 $=2$ 년, 맹방 해수욕장과 후 포항 $=1$ 년 $)$ 에 해당되는 자료들의 파랑장미도를 제시하였다. 이 그림들을 살펴보면 가장 북쪽에 위치한 공현진항과 남쪽 에 위치한 후포항의 주 파향은 NE로 나타났으나 그 사이에 위치한 맹방 해수욕장에서는 파향 $\mathrm{NNE}$ 와 $\mathrm{NE}$ 의 출현율이 거 의 비슷한 차이를 보였다. 
Table 1. Basic information at five video monitoring points including selected data part and period for analysis at each point

\begin{tabular}{lccccc}
\hline \hline $\begin{array}{c}\text { Beach monitoring } \\
\text { point }\end{array}$ & $\begin{array}{c}\text { Wave monitoring } \\
\text { point }\end{array}$ & $\begin{array}{c}\text { Shoreline } \\
\text { length }(\mathrm{m})\end{array}$ & $\begin{array}{c}\text { Total number of beachlines, } \\
\text { (Number of cameras) }\end{array}$ & $\begin{array}{c}\text { Number of selected } \\
\text { beachlines for analysis }\end{array}$ & $\begin{array}{c}\text { Period of selected } \\
\text { data for analysis }\end{array}$ \\
\hline Gyoam & Gonghyunjin & 640 & $11(3)$ & all & $2015.10 .01 \sim 2016.10 .01$ \\
Bongpo & $"$ & 1,000 & $20(4)$ & all & $2015.11 .15 \sim 2017.11 .15$ \\
Hamaengbang & Maengbang & 3,800 & $76(6)$ & all & $2014.12 .01 \sim 2015.12 .01$ \\
Wolgsongni & Hupo & 2,200 & $44(4+4)$ & $1 \sim 30$ & $2016.08 .11 \sim 2017.08 .11$ \\
Goraebul & $"$ & 4,300 & $86(2+4+4)$ & $1 \sim 55$ & $2016.08 .11 \sim 2017.08 .11$ \\
\hline
\end{tabular}

\section{2 해빈폭 자료 및 품질 개선}

비디오 모니터링 대상 5 개 해안의 해안선 길이와 카메라 및 기선 수 등의 기본 정보를 Table 1 에서 확인할 수 있다. Table 1의 카메라 수는 위치별로 설치된 카메라의 수를 표기 한 것으로, 월송리와 고래불의 경우 각각 2 곳 $(4+4)$ 과 3 곳 $(2+4+4)$ 의 설치 위치에 복수의 카메라가 설치되었다. 카메 라의 설치 위치와 설정한 기선은 Fig. 2의 지도에 표시되어 있다. 5 개 해안의 길이는 $640 \mathrm{~m}$ 에서 $4,300 \mathrm{~m}$ 에 이르기까지 다양하고, 이에 따라 카메라의 수와 $50 \mathrm{~m}$ 간격으로 해빈폭을 재는 기선의 수도 달라진다.

해빈폭 자료는 해안선의 변화 패턴을 나타냄으로서 침식 · 퇴적 양상에 대한 정보를 줄 수 있다. 다만 해빈폭 정보만으 로는 해수면 아래와 해안 단면의 변화에 대해서는 알기 어렵 다는 한계가 있다. 이와 같은 해빈폭 자료를 바탕으로 가능 한 한 정확한 반응 경향성을 확인하기 위해서는 해빈폭 자료 의 품질과 관측 기간을 최대한 확보할 필요가 있다. 특히 관 측기기로 계측한 파랑 자료에 비해 영상으로부터 추출한 해 빈폭 자료는 품질을 점검할 필요가 있고 개선의 여지도 큰 편 이다.

해빈폭 자료는 낮 시간 동안 매 30 분 간격의 영상 자료
를 분석하여 추출되는데, 낮 시간 동안에라도 기상 조건 및 기타 상황에 따라 자료 취득률이 현저히 떨어지는 경우가 발 생한다. 또한 비디오 영상으로부터 해안선을 자동적으로 추 출하는 과정에서 실제 해안선이 아닌 오류가 포함되는 경우 도 있다. 해빈폭 자료는 파랑자료와 함께 시계열의 형태로 분석하게 되므로 이러한 오류 시점이 포함되는 것을 피해야 한다.

본 연구에서는 이러한 특성을 반영하여 가능한 실제 해안 선에 가까운 해빈폭 자료가 구해지도록 개선 과정을 거쳤다. 해빈폭 자료는 기선과 기간에 따라 그 품질이 다양하고 이상 치 양상도 다르게 나타나므로 그 특성에 맞춰 개선 처리를 할 필요가 있다. Cho et al.(2014)의 방법을 참고하여 각 기선별 해빈폭 자료에 대해 이상치 진단과 제거가 자동적으로 이루 어지도록 적용하였다. Cho et al.(2014)은 원자료 시계열을 일 정한 간격(span)으로 평활화하고, 원자료 시계열과 평활화한 시계열 사이의 잔차에 대해 설정된 기준에 따라 자동으로 이 상치 진단을 하는 방안이다. 이때 평활화시의 적절한 간격과 이상치를 진단하는 기준은 자료 유형과 특성에 적합하게 적 용되어야 하므로 시행착오를 거쳐 설정하였다. 이러한 방법 으로 제거되지 않는 일부의 비정상적 오차에 대해서는 일정

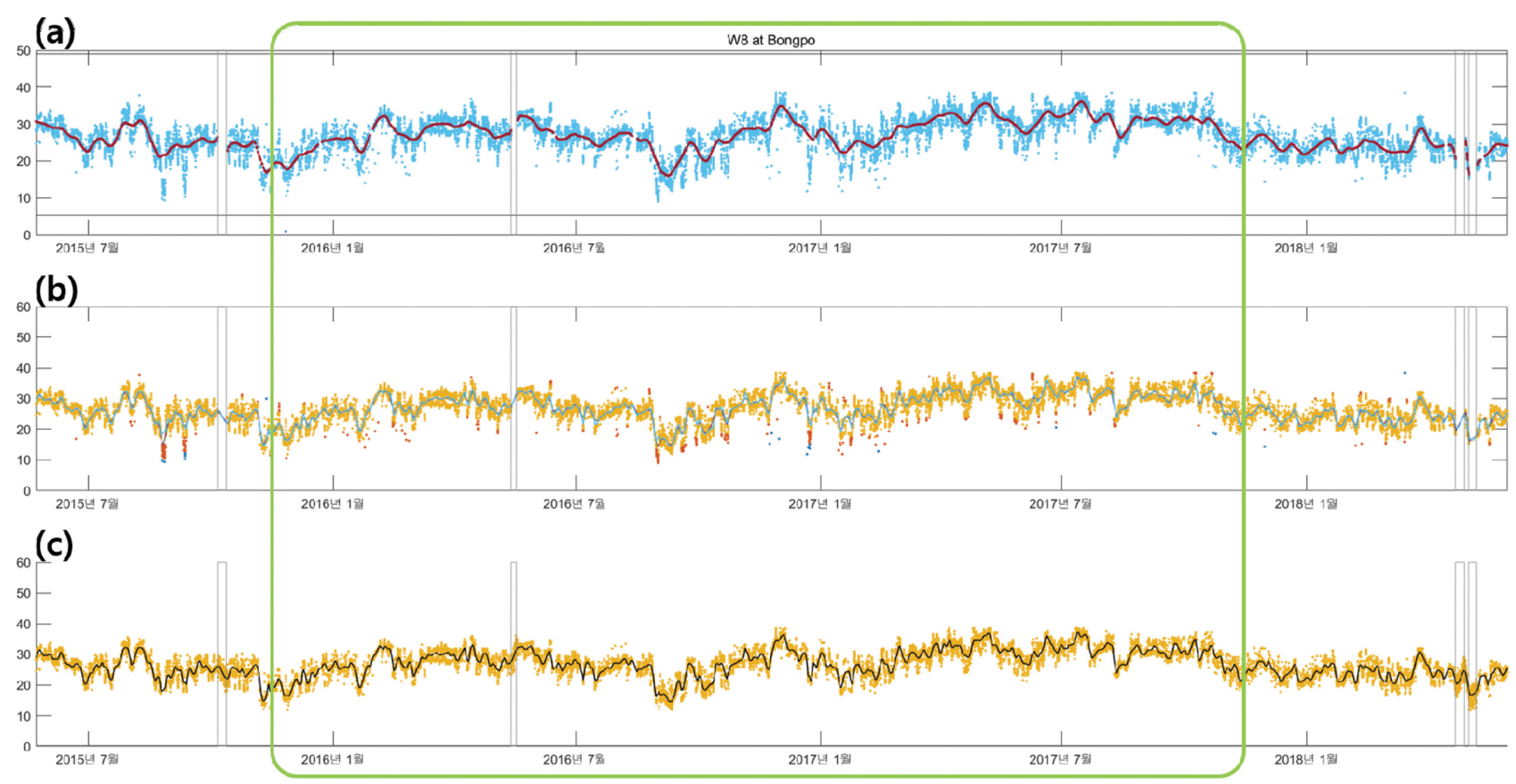

Fig. 5. Processes of a beach width (8th beachline at Bongpo) treatment for data improvement. 
구간과 기간에 대해 인위적으로 오차 범위를 설정해서 제거 하였다. 최종적으로 개선을 거친 해빈폭 자료는 매 시각 자 료로 리샘플링하여 분석에 활용하였다. Figs. 5 7은 이러한 해 빈폭 자료 처리 과정의 예시를 보여주고 있다.

Fig. 5는 자료품질이 비교적 양호한 봉포 해변의 8 번 기선 의 예시로서, 해빈폭 자료 개선 과정을 순차적으로 나타내었 다. Fig. 5(a)의 파란색 점이 영상 자료로부터 추출된 해빈폭 시계열자료이며, 그것을 기준으로 한 달 간격(span)으로 평활 화하여 오차 판별기준으로 삼았다. 오차 판별을 거쳐 남은 자
료에 대해 다시 5 일 간격 평활화를 실시(b)하고, 다시 1 시간 간격으로 보간하여 매시각의 해빈폭 자료를 취득(c)하였다. 여 기서 회색 수직선 사이의 좁은 구간은 해빈폭 자료가 결측된 시기의 구간을 표현한 것이다. 결측 구간은 인근 자료의 경 향과 잔차 성분을 조합한 성분으로 보간하였다.

Fig. 6 은 월송리 해안 12 번 기선의 해빈폭 처리 과정 예시 이다. Fig. 6(a)의 파란색과 붉은색 점으로 표현된 영상 자료 를 보면 순전히 영상자료의 오차로 보이는 값들이 겨울철을 중심으로 분포하고 있다. 이와 같이 확연히 오차로 보이는 위

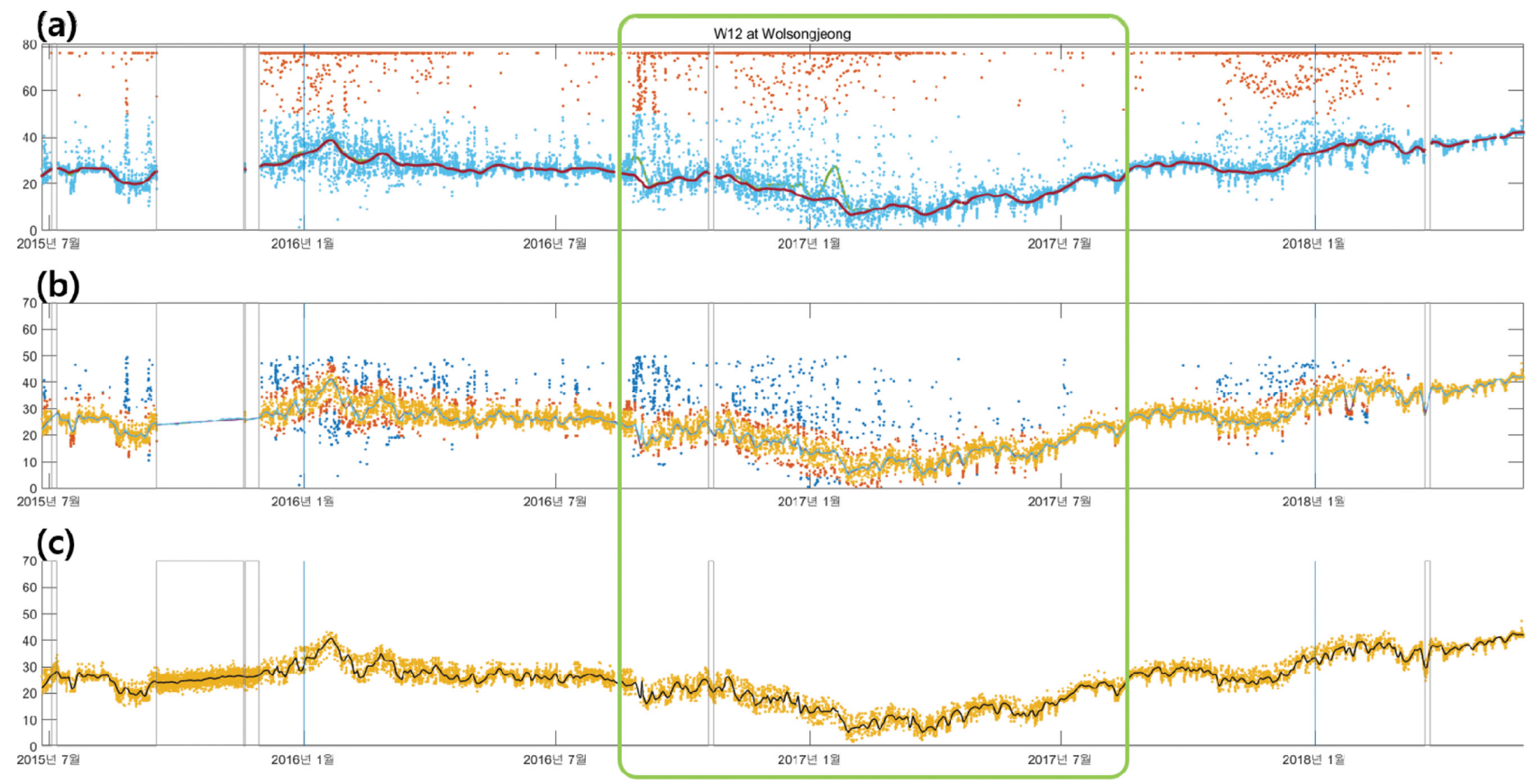

Fig. 6. Processes of a beach width (12th beachline at Wolsongni) treatment for data improvement.

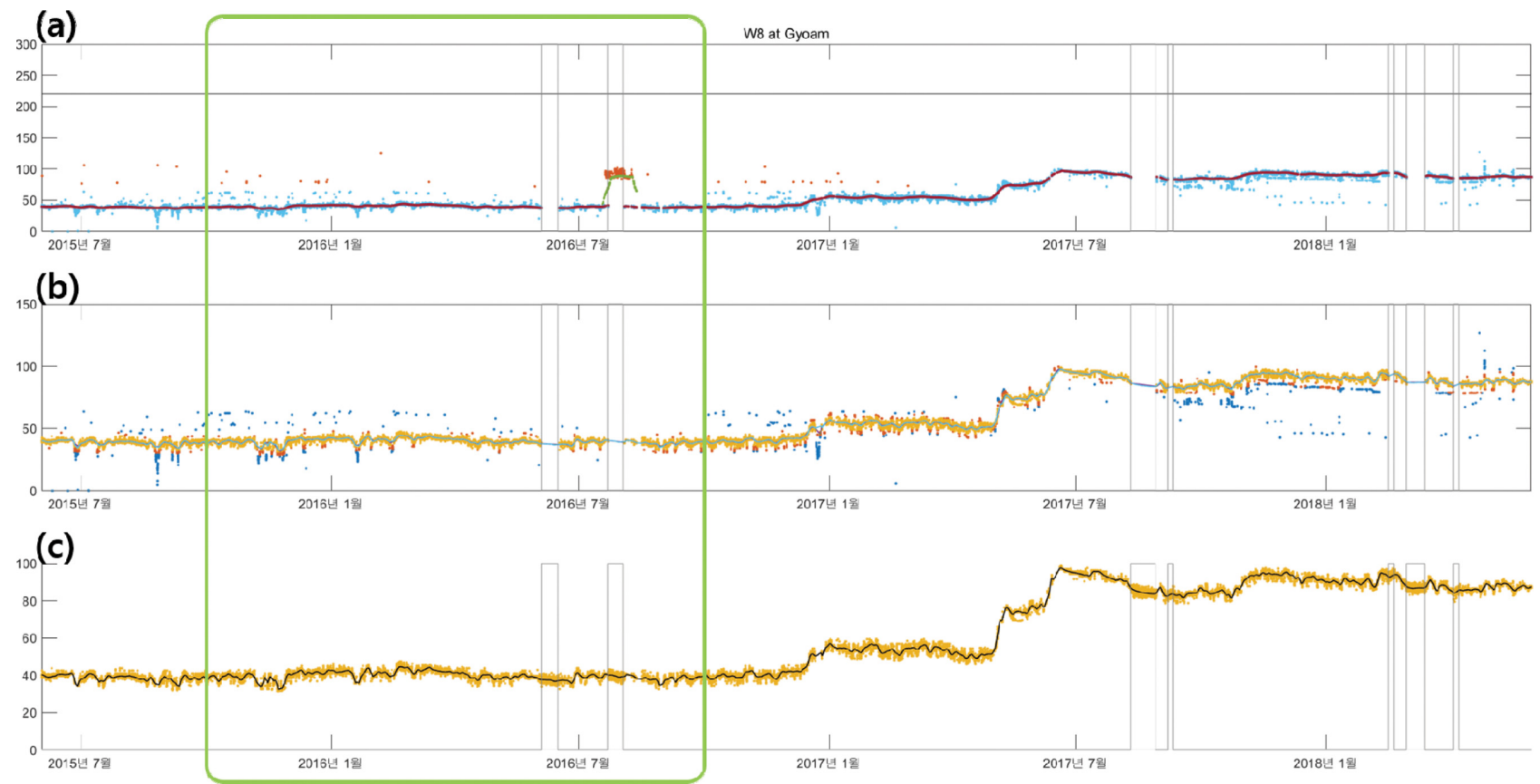

Fig. 7. Processes of a beach width (8th beachline at Gyoam) treatment for data improvement. 
치의 범위에 자료가 대량 분포하는 경우, 인위적으로 오차 범 위를 설정하여 이상치(붉은색 점)를 제거한다. 이후에는 앞의 봉포 8번 기선(Fig. 5)와 같은 방법으로 오차를 제거하고 결 측 구간을 보간한다. 그러나 월송리 12 번 기선의 2015년 가 을과 같이 결측 구간이 긴 경우, 보간된 값들이 실제 해빈의 변화를 충분히 반영했을 것으로 기대하기 어렵다. 이와 같이 결측 구간이 15 일 이상으로 긴 경우에는 해당 구간을 피해 서 분석대상 기간을 설정하였다.

Fig. 7은 교암 해안 8 번 기선의 예시로서, 양빈의 영향이 포 함된 해빈폭 자료의 개선 과정을 나타낸 것이다. 영상 자료 로부터 추출된 Fig. 7(a)의 점들을 보면 Fig. 5 의 봉포 8번 기선의 예시처럼 오차가 작은 편이다. 그러나 2017년 1월부 터 양빈과 같은 인위적인 영향으로 해빈폭이 크게 늘어나서 그 효과가 여름까지 지속된 것을 확인할 수 있다. 이와 같이 양빈을 했거나 양빈의 효과가 나타난 구간은 상관성 분석 시 에 해당 구간을 피해서 분석 기간을 설정하여 인위적 영향을 배제하였다.

파랑 자료의 기간과 겹쳐지는 기간 중에서 해빈폭 자료 처 리 과정을 통해 충분히 개선이 되지 않는 기선 및 기간은 배 제하고 연(年) 단위로 분석 기간을 구하였다. 최종적으로 분 석을 위해 선택된 해빈폭 기선과 기간은 Table 1 의 5,6 열과 같다. 월송리와 고래불 해안에서는 북편의 기선들이 대거 탈 락한 것을 확인할 수 있다. 이것은 월송리 북쪽 해안(구산리) 의 경우 해빈폭 추출 시 해안 전면에 설치된 이안제의 간섭 영향이 포함되어 있으며, 고래불 북쪽 해안의 경우에는 다른 지역 $(2048 \times 1536,4000 \times 3000)$ 보다 낮은 카메라 해상도 $(640 \times 480)$ 에 기인하는 것으로 파악된다.

\section{3. 상관성 분석}

\section{1 상관성 분석 변수}

해빈폭 자료는 분석 대상인 해안의 기선 수에 따라 11 개 에서 55 개에 이르는 수의 시계열 자료로 존재한다(Table 1). 파고, 주기, 파향의 시계열 자료로 존재하는 파랑 자료와 해 빈폭 자료의 전반적인 상관성을 검토하고자, 기선별 해빈폭 자료를 평균화하여 분석에 사용하였다. 즉, $N$ 개의 기선별 해 빈폭 $\left(W_{i}, i=1, \ldots, N\right)$ 을 각각 평균제거한 다음 전체기선에 대해 평균한 평균해빈폭 $B W$ 를 상관성 분석 시의 해빈폭값 으로 사용하였다.

$$
B W=\frac{1}{N} \sum_{i=1}^{N}\left(W_{i}-\frac{1}{N} \sum_{i=1}^{N} W_{i}\right)
$$

5 개 해안의 평균해빈폭 $(B W)$ 과 파랑자료(유의파고 $H_{m 0}$, 첨 두주기 $T_{p}$, 첨두파향 $\left.\theta_{p}\right)$ 의 기본적인 상관관계를 구한 결과는 Table 2 와 같다. 여기서 상관계수를 산정하는 방식은 가장 일 반적인 Pearson의 상관계수 공식(Pearson, 1895)을 사용하였 다. 독립인 두 변수 $x, y$ 의 상관계수 $c c$ 는 식(2)와 같이 정의 되며, 여기서 $T$ 는 자료 길이이고 $\bar{x}$ 와 $\bar{y}$ 는 각 변수의 평균 이다. 구해진 상관계수 $c c$ 의 부호와 절대값의 크기는 두 변 수 사이의 선형적 상관관계의 방향과 크기를 각각 나타낸다.

$$
c c=\frac{\sum_{j=1}^{T}\left(x_{i}-\bar{x}\right)\left(y_{i}-\bar{y}\right)}{\sqrt{\sum_{j=1}^{T}\left(x_{i}-\bar{x}\right)^{2}} \sqrt{\sum_{j=1}^{T}\left(y_{i}-\bar{y}\right)^{2}}}
$$

Table 2 의 결과를 보면 봉포 해빈의 경우 인근의 공현진항 의 파랑에 대해 $c c$ 의 절대값 크기가 0.50 이상으로 상당히 유 의미한 음의 상관관계가 얻어졌고(유의파고와 첨두주기를 기 준하여 각각 -0.62 와 -0.63$)$, 월송리와 고래불에서도 그보다 는 낮지만 인근 파랑에 대해 의미있는 상관관계가 나타났다 (유의파고 또는 첨두주기를 기준하여 -0.51 과 -0.50 ). 그리고 첨두파향과 해빈폭의 상관관계는 유의파고와 해빈폭, 또는 첨 두주기와 해빈폭의 상관관계보다는 낮게 나타났다. 한편, 교 암과 하맹방에서는 $c c$ 의 절대값 크기가 모두 0.50 미만으로 상관관계가 상당히 낮게 나타났다. 이와 같이 전체적인 상관 성이 낮은 지역에 대해서는 해당 지역 해빈폭과 파랑 자료의 상관성이 항상 낮은지 확인할 필요가 있다. 계절이나 파랑 조 건(높은 파고, 긴 주기, 직각 입사, 쇄파 등)의 변화에 따라 해빈폭의 반응 방향이 크게 달라짐으로 인해, 전체 상관관계 를 산정할 때에는 도리어 그 상관성이 상쇄되거나 희석된 것 일 수 있기 때문이다. 따라서 파랑 조건이나 계절적 조건을 달리하여 상관성을 검토해 볼 필요가 있다.

\section{2 파랑 조건별 분석}

조건별 상관성을 구하기에 앞서 변수들의 분포를 확인할 필 요가 있다. $H_{m 0}, T_{p}$ 및 $B W$ 의 확률분포를 구해 보면, $T_{p}$ 와 $B W$ 가 모두 정규분포에 가까운 형상을 가지고 있는 것과 달 리 $H_{m 0}$ 는 일반적인 파고의 Rayleigh 분포를 따르고 있다. 이 러한 $H_{m 0}$ 의 경우에도 $\log$ 를 취하는 간단한 변수 변환만으로 $\log \left(H_{m 0}\right)$ 가 정규분포에 가까운 형상으로 변환될 수 있다. Fig.

Table 2. Correlation coefficients between $B W$ and wave parameters at five beaches and the linked wave monitoring points

\begin{tabular}{lcccrr}
\hline \hline \multirow{2}{*}{ Beach monitoring point } & \multirow{2}{*}{ Wave monitoring point } & \multicolumn{3}{c}{ Correlation coefficient between $B W$ and wave parameter, } \\
\cline { 3 - 6 } & & $H_{m 0}$ & $\log \left(H_{m 0}\right)$ & $T_{p}$ & $\theta_{p}$ \\
\hline Gyoam & Gonghyeonjin & -0.25 & -0.26 & -0.12 & 0.18 \\
Bongpo & $"$ & -0.61 & -0.68 & -0.63 & -0.33 \\
Hamaengbang & Maengbang & -0.37 & -0.43 & -0.48 & -0.36 \\
Wolsongni & Hupo & -0.51 & -0.57 & -0.50 & -0.27 \\
Goraebul & $"$ & -0.48 & -0.49 & -0.49 & -0.33 \\
\hline
\end{tabular}




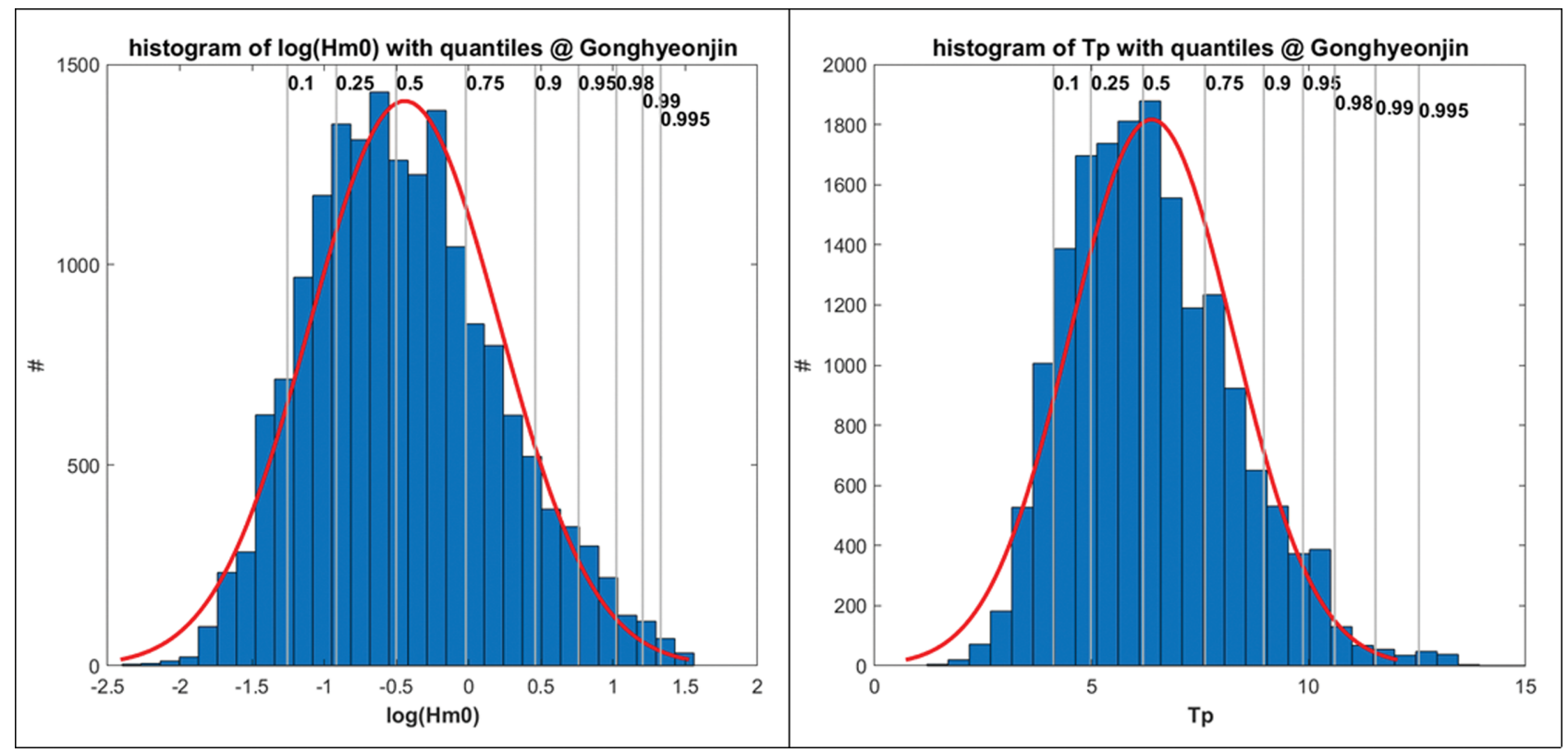

Fig. 8. Histograms of $\log \left(H_{m 0}\right)$ and $T_{p}$ with the non-exceedance probabilities and their quantiles (Gonghyeonjin).

8 에서 $\log \left(H_{m 0}\right)$ 와 $T_{p}$ 의 히스토그램들이 정규분포에 가까운 것 을 확인할 수 있다. 또한 Table 2에 제시한 것처럼 $H_{m 0}$ 와 $\log \left(H_{m 0}\right)$ 에 대한 해빈폭의 상관관계를 비교하면 후자가 다소 높은 상관관계를 보여주고 있다. 따라서 금후의 해빈폭과의 상관관계 분석에 있어서는 파고를 대표하는 값으로 $H_{m 0}$ 대 신 $\log \left(H_{m 0}\right)$ 를 사용하였다.

이와 같은 조건 변수들의 분포 형태를 바탕으로 적정 구간 으로 분할하여 조건을 설정할 수 있다. 밀도에 따라 가능한 한 균등하게 구간을 나누고자 파고·주기의 비초과확률 0.1 , $0.25,0.5,0.75,0.9,0.95,0.98,0.99,0.995$ 에 대한 분위수 (quantile)를 사용하였다. 해당 확률에 대한 파고 및 주기의 분 위수들은 Fig. 8의 $\log \left(H_{m 0}\right)$ 와 $T_{p}$ 의 히스토그램에서 회색 수 직선과 같이 구해진다.

한편 $\theta_{p}$ 의 확률분포를 구해 보면 Fig. 9의 히스토그램과 같 이 주파향 부근에서는 높은 밀도를 보이다가 점점 낮아지는



Fig. 9. A histogram of $\theta_{p}$ and directional segmentation (Gonghyeonjin).
형상을 보인다. 이와 같이 달라지는 출현율을 고려하여 히스 토그램의 회색 수직선과 같이 구간을 나누었다. N부터 ESE 까지는 $22.5^{\circ}$ 간격의 16 방위 기준으로 구한 파향 구간이며, 이후 $\mathrm{SE}$ 와 $\mathrm{S}$ 는 $33.75^{\circ}$ 간격으로, 그리고 $\mathrm{SW}, \mathrm{WNW}$ 는 $67.5^{\circ}$ 간격으로 구한 파향 구간이다 $\left(\mathrm{N}=326.25 ~ 11.25^{\circ}, \mathrm{NNE}\right.$ $=11.25 \sim 33.75^{\circ}, \mathrm{NE}=33.75 \sim 56.25^{\circ}, \mathrm{ENE}=56.25 \sim 78.75^{\circ}, \mathrm{E}$ $=78.75 \sim 101.25^{\circ}, \mathrm{ESE}=101.25 \sim 123.75^{\circ}, \mathrm{SE}=123.75 \sim 157.5^{\circ}$, $\mathrm{S}=157.5 \sim 191.25^{\circ}, \mathrm{SW}=191.25 \sim 258.75^{\circ}, \mathrm{WNW}=258.75 \sim$ $326.25^{\circ}$ ). 이와 같은 파향의 구간 분할은 본 연구의 분석 대 상인 동해안에 한하여 적용할 수 있을 것이다.

이와 같이 설정한 파고와 주기 및 파향의 구간별로 파랑변 수와 해빈폭의 상관관계를 구하고 박스플롯으로 변수들의 변 동 범위를 확인하였다. Figs. 10 12은 봉포 해안의 해빈폭과 공현진의 파고, 주기 및 파향에 대한 분석의 예시이다. 5 지 점 해빈에서의 파고 · 주기 · 파향 구간별 해빈폭과의 상관 관계 분석 결과는 Table 3 에 정리하였다.

Fig. 10은 파고의 분위수들을 기준으로 구간을 나누어 분 석한 것으로, 분위수에 의한 파고 구간별로 주기와 해빈폭 자 료들의 변동 범위와 파고 및 주기와 해빈폭의 상관계수를 확 인할 수 있다. Fig. 10(a)의 상단에 표시된 값들은 파고 구간 을 나눈 비초과확률과 그 구간에 속하는 자료 개수(\#)이며, 그 아래의 볼드체 숫자는 각 구간에서의 파고와 해빈폭의 상관 계수를 의미한다. (b)에서의 볼드체 숫자는 각 구간에서의 주 기와 해빈폭의 상관계수를 의미한다. 각 파고 구간에 해당하 는 주기와 해빈폭의 변동 범위는 Fig. $10(\mathrm{~b})$, (c)와 같고, 파 고가 높은 구간으로 갈수록 주기도 길어지고 해빈폭도 줄어 드는 것을 확인할 수 있다. 또한 파고가 높은 구간으로 갈수 록 해빈폭에서도 침식 효과가 커지는 것은 분명하지만, 각 파 고 구간 안에서 파고와 해빈폭 사이에는 유의미한 크기의 상 
Table 3. Correlation analysis results according to wave conditions

\begin{tabular}{|c|c|c|c|c|c|c|c|c|c|c|c|}
\hline \multirow{2}{*}{\multicolumn{2}{|c|}{$\begin{array}{c}\text { Classes } \\
\text { wrt } H_{m 0}, T_{p}\end{array}$}} & \multicolumn{10}{|c|}{ Upper bound non-exceedance probability or degree for each class } \\
\hline & & 0.1 & 0.25 & 0.5 & 0.75 & 0.9 & 0.95 & 0.98 & 0.99 & 0.995 & 1.0 \\
\hline \multirow{2}{*}{\multicolumn{2}{|c|}{ wrt $\theta_{p}$}} & 11.25 & 33.75 & 56.25 & 78.75 & 101.25 & 123.75 & 157.5 & 191.25 & 258.75 & 326.25 \\
\hline & & $\mathrm{N}$ & NNE & NE & ENE & $\mathrm{E}$ & ESE & SE & $\mathrm{S}$ & SW & WNW \\
\hline \multicolumn{12}{|c|}{ Gyoam $\left(100^{\circ}\right)$} \\
\hline \multirow{2}{*}{ wrt $H_{m 0}$} & $\mathrm{ccH}$ & -0.15 & -0.05 & -0.02 & -0.15 & -0.11 & 0.04 & -0.12 & -0.02 & 0.22 & -0.11 \\
\hline & $\mathrm{ccT}$ & 0.36 & 0.16 & 0.12 & 0.02 & -0.10 & -0.12 & -0.19 & 0.22 & -0.24 & -0.78 \\
\hline \multirow{2}{*}{ wrt $T_{p}$} & $\mathrm{ccH}$ & -0.04 & -0.19 & -0.23 & -0.23 & -0.36 & -0.43 & -0.25 & -0.33 & -0.88 & -0.80 \\
\hline & $\mathrm{ccT}$ & -0.02 & -0.02 & -0.10 & 0.06 & -0.07 & -0.05 & -0.09 & 0.13 & -0.31 & 0.14 \\
\hline \multirow{2}{*}{ wrt $\theta_{p}$} & $\mathrm{ccH}$ & -0.11 & -0.25 & -0.35 & -0.32 & -0.44 & -0.39 & -0.25 & -0.09 & -0.05 & -0.09 \\
\hline & $\mathrm{ccT}$ & 0.24 & -0.18 & -0.22 & 0.00 & -0.12 & -0.06 & -0.03 & 0.04 & 0.12 & 0.31 \\
\hline \multicolumn{12}{|c|}{ Bongpo $\left(53^{\circ}\right)$} \\
\hline \multirow[b]{2}{*}{ wrt $H_{m 0}$} & $\mathrm{ccH}$ & -0.21 & -0.17 & -0.22 & -0.20 & -0.21 & 0.07 & -0.08 & -0.07 & -0.24 & -0.23 \\
\hline & $\mathrm{ccT}$ & -0.20 & -0.31 & -0.41 & -0.39 & -0.34 & -0.22 & -0.36 & -0.39 & -0.63 & -0.70 \\
\hline \multirow{2}{*}{ wrt $T_{p}$} & $\mathrm{ccH}$ & -0.41 & -0.39 & -0.50 & -0.53 & -0.42 & -0.28 & -0.48 & -0.50 & -0.76 & -0.84 \\
\hline & $\mathrm{ccT}$ & -0.15 & -0.07 & -0.24 & -0.17 & -0.12 & -0.07 & -0.04 & -0.06 & -0.29 & 0.49 \\
\hline \multirow{2}{*}{ wrt $\theta_{p}$} & $\mathrm{ccH}$ & -0.52 & -0.54 & -0.64 & -0.67 & -0.64 & -0.44 & -0.53 & -0.62 & -0.53 & -0.58 \\
\hline & $\mathrm{ccT}$ & -0.46 & -0.56 & -0.60 & -0.49 & -0.42 & -0.33 & -0.38 & -0.56 & -0.48 & -0.20 \\
\hline \multicolumn{12}{|c|}{ Hamaengbang $\left(43^{\circ}\right)$} \\
\hline \multirow{2}{*}{ wrt $H_{m 0}$} & $\mathrm{ccH}$ & -0.04 & -0.17 & -0.10 & -0.12 & -0.05 & 0.00 & 0.07 & 0.04 & -0.12 & 0.39 \\
\hline & $\mathrm{ccT}$ & 0.00 & -0.24 & -0.29 & -0.28 & -0.38 & -0.39 & -0.62 & -0.67 & -0.69 & -0.77 \\
\hline \multirow{2}{*}{ wrt $T_{p}$} & $\mathrm{ccH}$ & -0.13 & -0.16 & -0.12 & -0.18 & -0.28 & -0.10 & 0.06 & 0.07 & -0.34 & -0.40 \\
\hline & $\mathrm{ccT}$ & 0.04 & -0.09 & -0.11 & -0.10 & -0.12 & -0.10 & 0.01 & 0.05 & -0.23 & 0.24 \\
\hline \multirow{2}{*}{ wrt $\theta_{p}$} & $\mathrm{ccH}$ & -0.37 & -0.41 & -0.27 & -0.41 & -0.06 & -0.23 & 0.03 & -0.02 & -0.20 & -0.20 \\
\hline & $\mathrm{ccT}$ & -0.54 & -0.56 & -0.43 & -0.33 & -0.10 & -0.24 & 0.12 & 0.14 & 0.22 & 0.04 \\
\hline \multicolumn{12}{|c|}{ Wolsongni $\left(70^{\circ}\right)$} \\
\hline \multirow{2}{*}{ wrt $H_{m 0}$} & $\mathrm{ccH}$ & -0.11 & -0.04 & -0.15 & -0.28 & 0.05 & -0.10 & -0.05 & 0.12 & -0.06 & -0.19 \\
\hline & $\mathrm{ccT}$ & -0.34 & -0.39 & -0.36 & -0.20 & 0.07 & 0.16 & 0.16 & -0.15 & -0.49 & -0.55 \\
\hline \multirow{2}{*}{ wrt $T_{p}$} & $\mathrm{ccH}$ & -0.44 & -0.43 & -0.51 & -0.47 & -0.29 & -0.04 & -0.04 & 0.04 & -0.03 & -0.58 \\
\hline & $\mathrm{ccT}$ & -0.04 & -0.10 & -0.26 & -0.05 & -0.04 & -0.08 & -0.17 & 0.16 & -0.15 & -0.51 \\
\hline \multirow{2}{*}{ wrt $\theta_{p}$} & $\mathrm{ccH}$ & -0.49 & -0.51 & -0.50 & -0.53 & -0.55 & -0.61 & -0.50 & -0.37 & -0.38 & -0.50 \\
\hline & $\mathrm{ccT}$ & -0.23 & -0.36 & -0.38 & -0.42 & -0.48 & -0.42 & -0.47 & 0.02 & 0.17 & 0.06 \\
\hline \multicolumn{12}{|c|}{ Goraebul $\left(63^{\circ}\right)$} \\
\hline \multirow{2}{*}{ wrt $H_{m 0}$} & $\mathrm{ccH}$ & -0.11 & -0.01 & -0.05 & -0.17 & -0.22 & 0.03 & 0.03 & -0.01 & -0.16 & -0.21 \\
\hline & $\mathrm{ccT}$ & -0.15 & -0.28 & -0.35 & -0.30 & -0.19 & 0.04 & 0.22 & 0.19 & -0.27 & -0.46 \\
\hline \multirow{2}{*}{ wrt $T_{p}$} & $\mathrm{ccH}$ & -0.04 & -0.27 & -0.26 & -0.36 & -0.26 & -0.24 & -0.18 & 0.19 & 0.09 & -0.20 \\
\hline & $\mathrm{ccT}$ & -0.09 & -0.06 & -0.25 & -0.04 & -0.08 & -0.05 & -0.04 & 0.04 & -0.10 & -0.50 \\
\hline \multirow{2}{*}{ wrt $\theta_{p}$} & $\mathrm{ccH}$ & -0.50 & -0.45 & -0.38 & -0.53 & -0.51 & -0.36 & -0.14 & -0.14 & -0.10 & -0.01 \\
\hline & $\mathrm{ccT}$ & -0.28 & -0.44 & -0.35 & -0.43 & -0.40 & -0.16 & -0.16 & 0.08 & 0.05 & -0.06 \\
\hline
\end{tabular}

관관계가 보이지는 않았다. 이와 반대로 주기와 해빈폭 사이 에는 비초과확률 0.99 이상의 높은 파고 구간 $\left(H_{m 0} \geq 3.3 \mathrm{~m}\right)$ 에서 상당히 큰 음의 상관관계를 보였다 $(-0.63,-0.70)$.

Table 3은 봉포의 Fig. 10과 같은 상관계수 분석 결과를 다 른 지점에 대해서도 제시하고 있다. Fig. 8과 Fig. 9의 파랑 조건(파고와 주기의 분위수, 파향 구간)에 따른 해빈폭과의 상 관계수를 각 지점별로 보여주고 있다. 구간을 나누는 기준이 되는 파랑 변수에 따라 wrt $H_{m 0}$ (파고의 분위수를 기준으로 구 간을 나눈 것), wrt $T_{p}$ (주기의 분위수 기준으로 구간을 나눈 것), wrt $\theta_{p}$ (파향 구간 별로 구간을 나눈 것)로 표기하였다.
각 구간에 따른 상관계수는 해빈폭과 파고 $(\mathrm{ccH})$, 해빈폭과 주 기(ccT)에 대하여 산정되었으며, 각 지점명과 함께 기록된 각 도는 각 해안선의 직각방향을 의미한다.

이에 따라 Fig. 10 의 봉포의 분석과 같은 다른 4 개 지점의 파고 구간별 분석 결과는 각 지점별로 $\mathrm{wrt} H_{m 0}$ 에서 확인할 수 있으며, 주기와 해빈폭의 상관관계(ccT)를 보면 비초과확 률 0.99 이상의 높은 파고 구간에서 $\mathrm{ccT}$ 가 그 이전 구간에 비해 확연히 크게 나타나고 있음을 알 수 있다. 이러한 상관 관계의 구간별 변화는 어느 수준 이상의 높은 파고로 파랑이 발생할 때 주기에 비례해서 해빈폭의 감소가 심화됨을 의미 

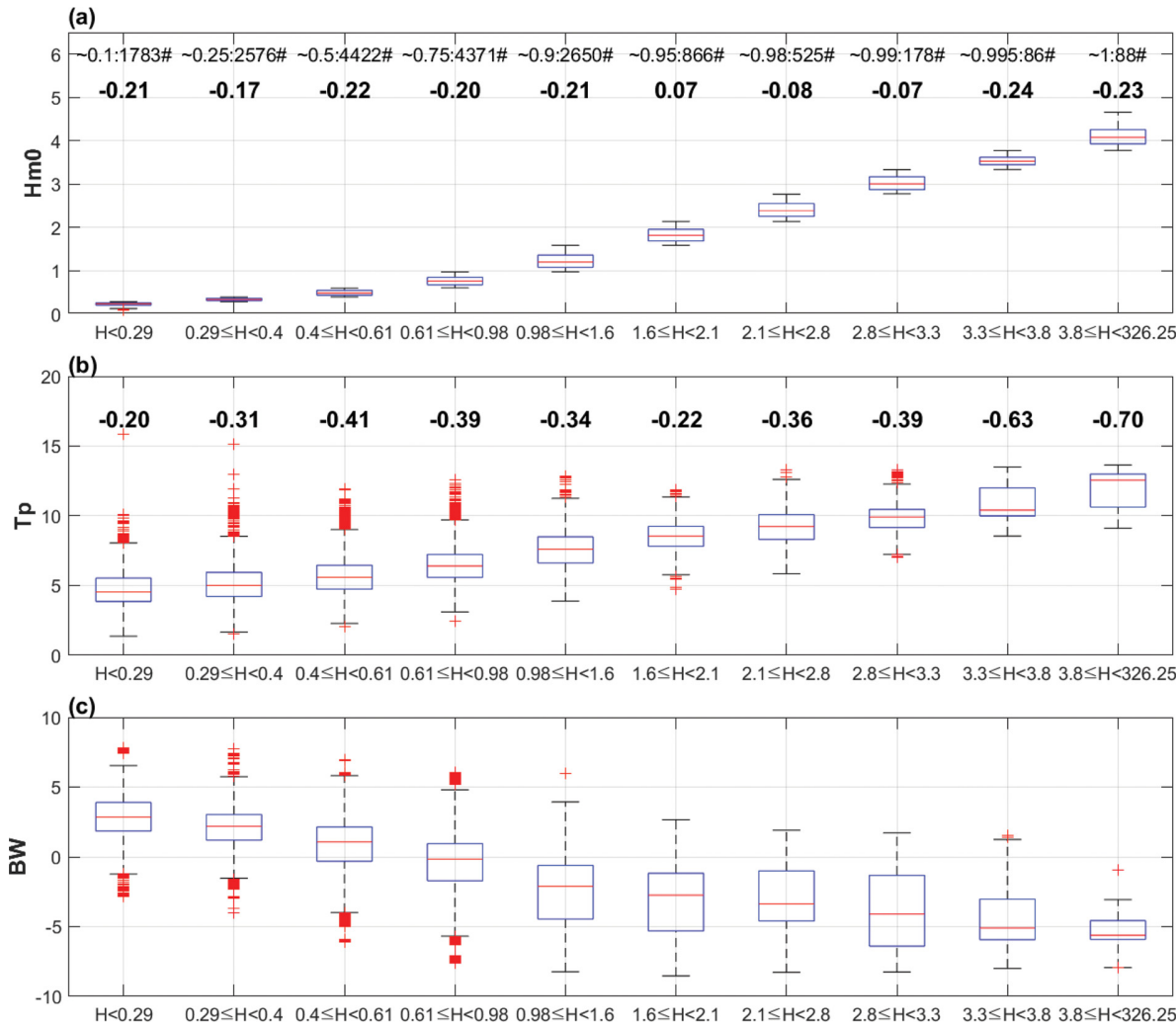

Fig. 10. Boxplots according to classes of $H_{m 0}$ segmented by non-exceedance probabilities (Gonghyeonjin and Bongpo): (a) boxplots of $H_{m 0}$ with numbers of data at each class and correlation coefficients between $H_{m 0}$ and $B W$. (b) boxplots of $T_{p}$ with correlation coefficients between $T_{p}$ and $B W$. (c) boxplots of $B W$.


Fig. 11. Boxplots according to classes of $T_{p}$ segmented by non-exceedance probabilities (Gonghyeonjin and Bongpo) : (a) boxplots of $H_{m 0}$ with correlation coefficients between $H_{m 0}$ and $B W$. (b) boxplots of $T_{p}$ with numbers of data at each class and correlation coefficients between $T_{p}$ and $B W$. (c) boxplots of $B W$. 

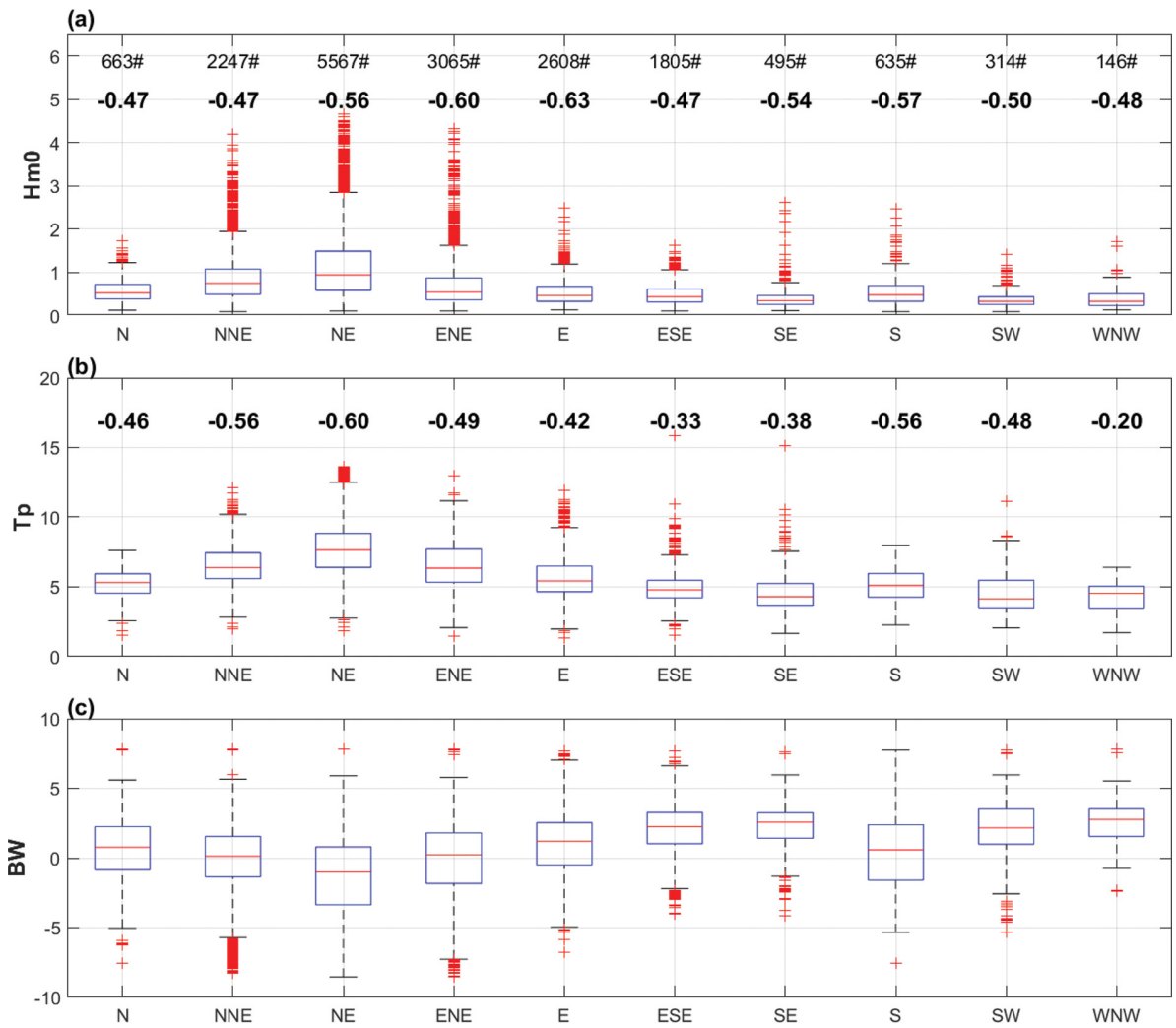

Fig. 12. Boxplots according to classes of segmented $\theta_{p}$ (Gonghyeonjin and Bongpo): (a) boxplots of $H_{m 0}$ with numbers of data at each class and correlation coefficients between $H_{m 0}$ and $B W$. (b) boxplots of $T_{p}$ with correlation coefficients between $T_{p}$ and $B W$. (c) boxplots of $B W$.

한다. 반면에 해당 구간(비초과확률 0.99 이상의 높은 파고 구 간)에서 파고와 해빈폭의 상관관계 $(\mathrm{ccH})$ 는 다른 구간과 비등 한 수준을 보인다. 이것은 비초과확률 0.99 이상 정도의 높 은 파고의 파랑이 발생하는 경우에, 상대적으로 더 높은 파 고로 발생한다고 해서 해빈폭의 감소가 심화되는 것은 아님 을 뜻한다.

Fig. 11은 주기의 분위수들을 기준으로 구간을 나누어 분 석한 것으로, 주기 구간별로 파고와 해빈폭 자료들의 변동 범 위와 파고 및 주기와 해빈폭의 상관계수를 확인할 수 있다. Fig. 11(a)에서의 볼드체 숫자는 각 구간에서의 파고와 해빈 폭의 상관계수를 의미한다. Fig. 11(b)의 상단에 표시된 값들 은 주기 구간을 나눈 비초과확률과 그 구간에 속하는 자료 개 수 $(\#)$ 이며, 그 아래의 볼드체 숫자는 각 구간에서의 주기와 해 빈폭의 상관계수를 의미한다. 각 주기 구간에 해당하는 파고 와 해빈폭의 변동범위는 Fig. 11(a), (c)와 같고, 주기가 긴 구 간으로 갈수록 파고도 높아지고 해빈폭도 줄어드는 것을 확 인할 수 있다. 이와 같이 주기가 긴 구간으로 갈수록 해빈폭 의 감소가 심화되는데, 비초과확률 0.99 이상의 긴 주기 구 간 $\left(T_{p} \geq 12 \mathrm{sec}\right)$ 에서 파고와 해빈폭 사이에는 상당히 큰 음의 상관관계가 나타났다 $(-0.76,-0.84)$. 이것은 어느 수준 이상 의 긴 주기의 파랑이 내습할 때는 파고에 비례해서 해빈폭의 감소가 심화됨을 의미한다.

Table 3에서 봉포 이외의 다른 지점들의 주기 구간별 분석
결과를 보면(wrt $T_{p}$ 참조), 비초과확률 0.99 이상의 긴 주기 구간에서 파고와 해빈폭의 상관관계 $(\mathrm{ccH})$ 가 그 이전 구간에 비해 확연히 크게 나타나고 있다. 이러한 상관관계의 주기 구 간별 변화는 어느 수준 이상의 긴 주기로 파랑이 발생할 때 파고에 비례해서 해빈폭의 감소가 심화됨을 의미한다. 반면 에 해당 구간(비초과확률 0.99 이상의 높은 주기 구간)에서 주기와 해빈폭의 상관관계 $(\mathrm{ccH})$ 는 다른 구간과 비등한 수준 을 보인다. 이것은 비초과확률 0.99 이상 정도의 긴 주기의 파랑이 발생하는 경우에, 상대적으로 더 긴 주기로 발생한다 고 해서 해빈폭의 감소가 심화되는 것은 아님을 뜻한다. 예 외적으로 고래불의 경우에만 긴 주기 구간에서 $\mathrm{ccH}$ 가 의미 있게 높은 값으로 나타나지 않고 오히려 ccT가 상승한 결과 를 보여주었다.

Fig. 12는 Fig. 9 와 같이 나눈 파향 구간에 따라 파고 및 주기와 해빈폭의 상관성을 분석한 것으로, 파향 구간별로 파 고 및 주기와 해빈폭 자료들의 변동 범위와 파고 - 주기와 해 빈폭의 상관계수를 확인할 수 있다. Fig. 12(a)의 상단에 표 시된 값들은 파향 구간별 자료 개수(\#)이며, 그 아래의 볼드 체 숫자는 각 구간에서의 파고와 해빈폭의 상관계수를 의미 한다. (b)에서의 볼드체 숫자는 각 구간에서의 주기와 해빈폭 의 상관계수를 의미한다). Fig. 12(a)와 (b)의 파고 및 주기에 대한 박스플롯을 보면 봉포 해안과 연계된 공현진 파랑은 $\mathrm{NE}$ 방향으로 가장 많이 발생하고(5567\#) 파고 및 주기도 가장 큰 
값으로 나타난다. 이와 더불어 Fig. 4의 파랑장미도에서도 NE 방향이 주파향으로 나타나고 있다. Fig. 12(c)의 해빈폭 변동 범위와 중앙값을 보아도 해당 $\mathrm{NE}$ 파향에 대해 침식이 가장 활발했던 것으로 보인다. 이와 더불어 파향 구간에 따른 해 빈폭의 반응을 분석하기 위해서는 내습하는 파랑에 면하는 해 안선의 각도도 중요하게 고려해야 한다. 일반적으로 해안선 이 완전한 일직선으로 형성되지는 않으나 본 연구에서 대상 으로 하는 해안에 대략적인 직선을 가상하고 해안선 직각방 향을 구하고자 하였다. Fig. 2의 지도에서와 같이 정북을 $0^{\circ}$ 로 하고 시계 방향으로 해안선 직각 방향을 측정하면, 교암 $100^{\circ}(\mathrm{E})$, 봉포 $53^{\circ}(\mathrm{NE})$, 하맹방 $43^{\circ}(\mathrm{NE})$, 월송리 $70^{\circ}(\mathrm{ENE})$, 고래불 $63^{\circ}(\mathrm{ENE})$ 로 구할 수 있다. 따라서 봉포의 해안선 직 각 방향은 $53^{\circ}$ 로 $\mathrm{NE}$ 방향 $\left(\mathrm{NE}=33.75 \sim 56.25^{\circ}\right)$ 에 해당되며 주파향과 일치하고 있다. 이와 같은 경우 주파향을 중심으로 해빈폭의 침식이 우세해 보이고(Fig. 12(c)) 파고 및 주기와 해빈폭 사이의 상관관계도 크게 나타나고 있다(Fig. 12(a)와 (b)).

Table 3의 다른 4개 지점의 파향 구간별 상관성 분석 결과 (wrt $\theta_{p}$ 참조)도 봉포 해빈의 경우와 같이 주파향과 해안선 직 각 방향을 함께 참조할 필요가 있다. 파향 구간별 해빈폭의
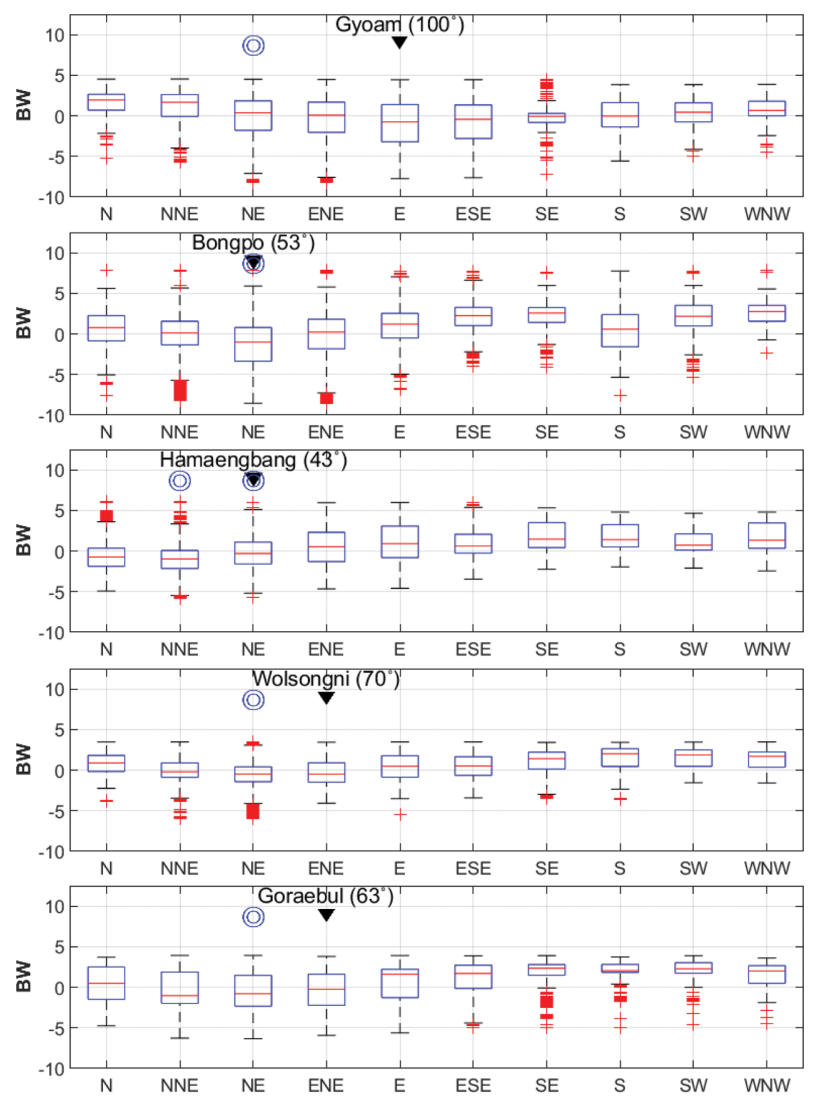

Fig. 13. Boxplots of $B W$ according to wave direction classes at five beaches (@): principal wave directions of the nearby wave monitoring data, $\boldsymbol{\nabla}$ : perpendicular directions to each shoreline. Each angles are enclosed in brackets, respectively).
변동 범위는 Fig. 13에서 해안선 직각 방향 및 주파향과 더 불어 박스플롯으로 확인할 수 있다. 각 해빈 지점 명과 그 해 안선의 직각 방향이 $\boldsymbol{\nabla}$ 로 해당 방향 구간을 표시하고 있으 며, 여기서 각도는 $0^{\circ}$ 가 $\mathrm{N}, 90^{\circ}$ 가 $\mathrm{E}, 180^{\circ}$ 가 $\mathrm{S}$ 를 각각 나타 낸다. 이와 더불어 ()로 표기된 것은 주파향을 가리킨다. $\mathrm{NNE}$ 와 NE에서의 출현율이 비슷한 맹방과 연계된 하맹방의 경우에만 주파향을 복수로 표기하였다.

Fig. 13의 다섯 지점을 비교해 보면 봉포 해빈은 주파향과 해안선 직각 방향이 일치하고 있고, 교암을 제외한 다른 해 빈도 주파향과 해안선 직각 방향이 인접해 있다. 파향 구간 별로 해빈폭의 박스플롯을 보면 교암을 제외한 전 해빈에서 주파향이 가리키는 구간에서 다른 파향 구간에 비해 해빈폭 이 많이 감소된 것으로 나타났다. 이것은 주파향이 해안선 직 각 방향에 인접한 경우, 주파향으로 오는 파랑에 의해 침식 이 심화됨을 의미한다. 이에 더하여 Table 3 의 wrt $\theta_{p}$ 상관 계수 분석 결과를 지점별로 살펴보면, 해안선 직각 방향과 더 불어 주파향 인근에서 파고 - 주기와 해빈폭 사이의 상관성 이 비교적 높게 나타났다.

\section{3 월별 분석}

계절적으로 나타나는 파랑과 해빈폭 변화의 상관성을 확인 하기 위하여 해빈폭과 파랑의 월별 분석을 실시하였다. 계절
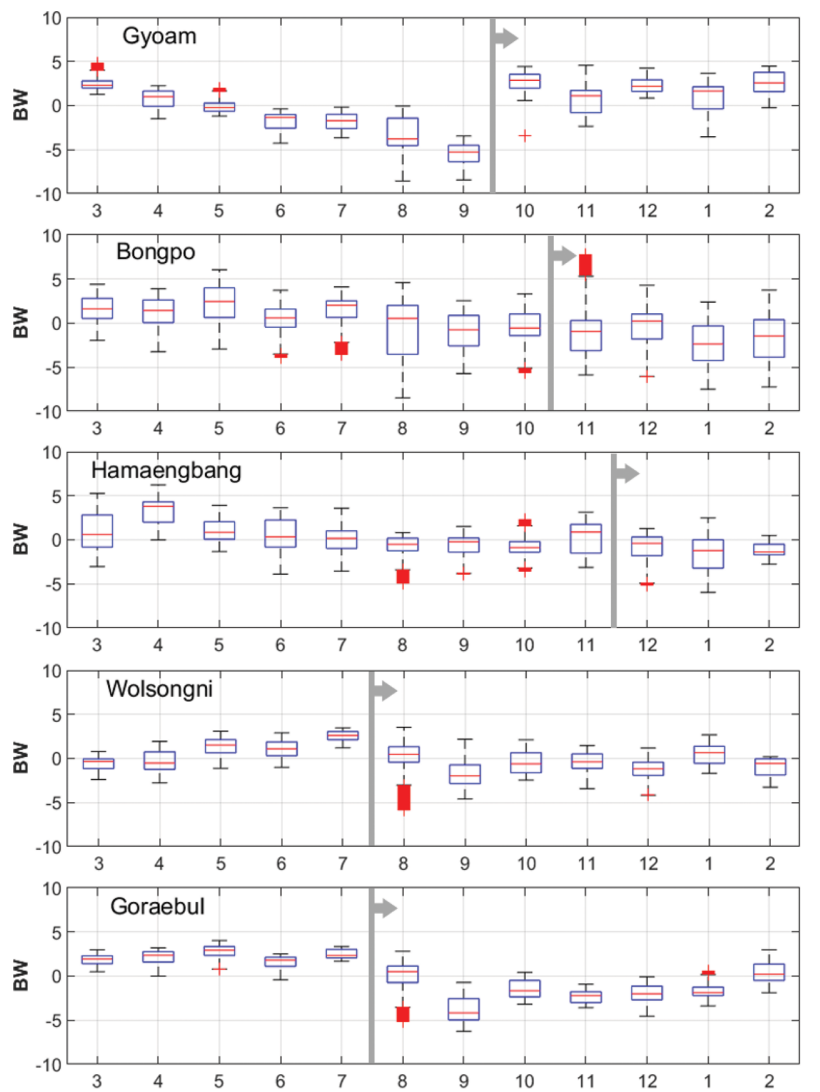

Fig. 14. Boxplots of monthly (March to February) $B W$ at five beaches: the gray vertical lines and arrows indicate the starting point of each data. 
Table 4. Monthly mean and maximum of $H_{m 0}$ and $T_{p}$ at each wave monitoring point

\begin{tabular}{|c|c|c|c|c|c|c|c|c|c|c|c|c|}
\hline Month & 3 & 4 & 5 & 6 & 7 & 8 & 9 & 10 & 11 & 12 & 1 & 2 \\
\hline \multicolumn{13}{|c|}{ Gonghyeonjin (Gyoam) } \\
\hline \multirow{2}{*}{$\begin{array}{c}H_{m 0} \mu \\
\max .\end{array}$} & 0.57 & 0.68 & 0.47 & 0.62 & 0.58 & 0.72 & 0.83 & 0.63 & 1.56 & 0.74 & 1.02 & 0.79 \\
\hline & 2.37 & 2.04 & 2.61 & 1.82 & 2.36 & 3.47 & 2.63 & 1.99 & 4.66 & 3.58 & 4.38 & 3.53 \\
\hline \multirow{2}{*}{$\begin{array}{c}T_{p} \mu \\
\max .\end{array}$} & 6.05 & 6.30 & 5.58 & 6.09 & 5.47 & 5.43 & 6.46 & 6.60 & 7.76 & 6.74 & 7.41 & 6.77 \\
\hline & 12.83 & 11.13 & 12.96 & 11.68 & 8.90 & 15.85 & 11.71 & 13.62 & 13.49 & 11.30 & 13.46 & 11.72 \\
\hline \multicolumn{13}{|c|}{ Gonghyeonjin (Bongpo) } \\
\hline \multirow{2}{*}{$\begin{array}{c}H_{m 0} \mu \\
\max .\end{array}$} & 0.66 & 0.67 & 0.57 & 0.66 & 0.50 & 0.74 & 0.73 & 0.98 & 1.31 & 0.96 & 1.03 & 0.88 \\
\hline & 2.82 & 2.04 & 2.95 & 2.67 & 2.36 & 3.47 & 2.69 & 4.32 & 4.66 & 4.51 & 4.38 & 3.53 \\
\hline \multirow{2}{*}{$\begin{array}{l}T_{p} \mu \\
\max .\end{array}$} & 6.09 & 6.14 & 5.68 & 6.00 & 5.01 & 5.72 & 6.16 & 6.50 & 7.60 & 7.17 & 7.50 & 7.10 \\
\hline & 12.83 & 11.13 & 12.96 & 12.27 & 8.90 & 15.85 & 11.71 & 11.15 & 13.49 & 13.64 & 13.46 & 11.93 \\
\hline \multicolumn{13}{|c|}{ Maengbang (Hamaengbang) } \\
\hline \multirow{2}{*}{$\begin{array}{c}H_{m 0} \mu \\
\max .\end{array}$} & 0.89 & 0.79 & 0.47 & 0.69 & 0.52 & 0.73 & 0.91 & 0.73 & 1.56 & 1.09 & 1.32 & 1.13 \\
\hline & 3.01 & 2.50 & 1.33 & 3.67 & 2.41 & 5.13 & 3.80 & 2.11 & 4.67 & 3.18 & 3.12 & 3.32 \\
\hline \multirow{2}{*}{$\begin{array}{l}T_{p} \mu \\
\max .\end{array}$} & 7.10 & 6.21 & 5.26 & 6.08 & 5.31 & 6.14 & 6.35 & 6.87 & 7.77 & 7.49 & 7.82 & 7.61 \\
\hline & 12.62 & 9.68 & 9.52 & 10.96 & 9.96 & 11.60 & 11.50 & 14.18 & 13.45 & 12.82 & 12.94 & 12.89 \\
\hline \multicolumn{13}{|c|}{ Hupo (Wolsongni, Goraebul) } \\
\hline \multirow{2}{*}{$\begin{array}{c}H_{m 0} \mu \\
\max .\end{array}$} & 0.94 & 0.85 & 0.67 & 0.73 & 0.53 & 0.92 & 1.03 & 1.11 & 1.26 & 1.17 & 1.22 & 1.23 \\
\hline & 3.16 & 2.47 & 2.94 & 3.41 & 1.49 & 3.89 & 2.98 & 3.36 & 3.99 & 4.03 & 3.50 & 3.12 \\
\hline \multirow{2}{*}{$\begin{array}{l}T_{p} \mu \\
\max .\end{array}$} & 6.36 & 6.01 & 5.83 & 6.02 & 4.72 & 5.91 & 6.64 & 6.54 & 7.59 & 7.76 & 7.91 & 7.77 \\
\hline & 10.68 & 10.61 & 10.25 & 12.25 & 7.15 & 11.75 & 12.35 & 11.52 & 12.59 & 14.01 & 11.62 & 11.51 \\
\hline
\end{tabular}

unit: $H_{m 0}(\mathrm{~m}), T_{p}(\mathrm{sec})$.

에 따른 해빈폭의 변화를 보기 위해 Fig. 14에서는 춘계인 3 월부터 동계인 2 월까지의 순서로 다섯 지점의 해빈폭 박스플 롯을 나타내었으나, 실제 각 해안의 자료의 시작 기간은 각 기 다르다. Table 1에 표시한 분석 기간에 따르면 교암은 10 월, 봉포는 11 월, 하맹방은 12 월, 월송리와 고래불은 8 월부터 실제 자료가 시작되었다. 실제 자료의 시작 시점이 표기된 세 로축과 화살표를 기준으로 보면, 교암은 해빈폭이 상당히 줄 어든 상태에서 자료가 끝나고 있으며 나머지 4지점은 비슷하 거나 살짝 증가한 상태에서 자료가 끝나고 있다. 다섯 지점 의 박스플롯을 비교해 보면 월이나 계절별 시점에 따른 해빈 폭 변화의 일관된 경향을 발견하기는 어렵다. 다만 추계인 8 월의 해빈폭을 보면(Fig. 14) 박스의 크기가 상당히 크거나, 침식 쪽(음의 방향)의 이상치가 발달한 것을 볼 수 있다. Table 4의 월별 파고 - 주기의 평균을 확인하면 전 지점에서 8 월의 평균 파고가 가장 높은 것은 아니지만 5 7월에 비하 면 확연히 상승하였다. 실제로 파랑자료의 시계열을 살펴보 면 태풍의 영향으로 인해 8 월 중에 큰 파랑이 발생했음을 확 인할 수 있다. 태풍 기록을 확인하면, 하맹방에는 고니(2015 년 8월 15 26일), 교암, 봉포, 월송리, 고래불에는 곤파스 (2016년 8월 20 21일)와 라이언록(2016년 8월 19 31일)의 영향이 있었던 것으로 판단된다. 따라서 하계에서 추계로 넘 어가는 시점에 태풍의 영향을 받게 되면 해빈폭이 평균 대비 상당히 후퇴한 상태에서 파고가 커지는 추계를 맞이하게 된 다. 교암의 경우 전년 대비 크게 후퇴한 해빈폭으로 나타난 것은 다른 영향을 배제할 수는 없으나 태풍 곤파스와 라이언
록에 연달아 영향을 받은 까닭으로 보인다.

Table 4의 월별 파고 · 주기의 평균을 관측 지점에 따라 보 면, 공현진과 맹방에서는 모두 11 월과 1 월에 파고와 주기가 모두 큰 값으로 나타나고 있다. 이와 연계된 교암, 봉포, 하 맹방의 해빈폭 변화를 보면(Fig. 14) 11월과 1월의 해빈폭 변 화가 상대적으로 컸으며 이는 증대된 동계 파랑에 의한 것으 로 생각할 수 있다. 다만 월송리와 고래불의 해빈폭과 연계 된 후포에서는 11월에 파고가 가장 높지만 12 2월에도 비등 하게 높은 월평균 파고를 보이고 있다. 이에 따라 동계에는 월송리와 고래불 해빈폭의 변동폭이 일정하게 유지되는 양상 을 보인다.

\section{4. 토의 및 결론}

연안의 침식 - 퇴적은 다양한 조건 하에서 비선형적으로 발 생하는 복잡한 현상이지만, 유사를 이동시키는 동력인 파랑 과 침식 · 퇴적을 대변하는 해빈폭 사이에는 밀접한 상관성 이 있을 것으로 기대된다. 그러나 실제로 파고 - 주기와 해 빈폭 사이에 상관 분석을 하면, 기대와 달리 유의미한 수준 의 상관성을 얻지 못하는 경우가 많다(Ministry of Oceans and Fisheries, 2016, 2017). 실제로 본 논문의 Table 2에서 도 이러한 사실을 확인할 수 있다. 이것은 전술한 바와 같이 해안의 변화가 여러 환경 조건에 따라 반응하는 상당히 비선 형적인 과정이기 때문이다. 본 연구에서는 파랑 조건 또는 기 간에 따라 파랑변수와 해빈폭의 상관성을 분석하여 전체적으 
로 상관성을 구할 때 발생하는 상쇄효과를 피하고자 했다. - 이와 같이 파랑 조건에 따라 상관성을 분석하면, 파고 - 주 기와 해빈폭 사이에 뚜렷한 상관성이 나타나는 주기와 파 고 구간을 발견할 수 있다. 비초과확률 0.99 이상의 파고 . 주기 구간에서의 해빈폭과의 상관관계를 분석하면, 파고가 높은 구간에서는 주기와 해빈폭의 상관관계가 뚜렷하게 크 고(- 방향) 주기가 긴 구간에서는 파고와 해빈폭의 상관관 계가 뚜렷하게 큰 것(- 방향)을 볼 수 있었다. 다시 말하면, 파고가 충분히 높은 경우에는 해빈폭이 주기에 비례해서 줄 어들고 주기가 충분히 긴 경우에는 해빈폭이 파고에 비례 해서 줄어든다는 것을 의미한다. 따라서 침식 문제가 있을 때 파고만을 위주로 설계하거나 대처하는 것은 비효율적일 수 있으며, 주기와의 관계에서 파고에 의한 침식 영향이 반 감되거나 증가하는 수준을 정밀히 분석할 필요가 있다.

- 파향 구간에 따른 상관성 분석에서는 주파향과 해안면의 직 각 방향이 일치하거나 인접한 해빈에서는(4개소: 봉포, 하 맹방, 월송리, 고래불) 주파향이 속한 구간의 파향으로 침 입해 올 때 해빈폭의 감소가 심화되는 것으로 나타났다. 반 면 주파향 $(\mathrm{NE})$ 과 해안선 직각 방향 $\left(\mathrm{E}, 100^{\circ}\right)$ 이 상이한 교 암의 경우에는 주파향 대신 해안선 직각 방향에 가까운 파 랑이 입사할 때 해빈폭의 감소가 심화되었다. 교암 해빈은 다른 4 개소의 해빈과는 달리 전면의 항만(문암항)과 암초 에 의해 $\mathrm{NE}$ 계열의 파에 대해 차폐되어 있어서 결과적으 로 동계의 폭풍파가 회절되어 $\mathrm{E}$ 계열 파향의 파가 해빈으 로 침입하기 때문인 것으로 판단된다. 만일 일부 해안에 대 해서 집중적으로 현장 조사를 실시하고자 한다면, 주파향 과 해안선 직각 방향이 일치하는 곳을 우선적으로 선택하 는 것이 유리할 것이다.

- 기간에 따른 해빈폭과 파랑의 상관성은 뚜렷한 계절적 경 향을 보여주지는 못했으나, 겨울이 시작하는 11월 즈음에 평균 파고가 가장 커지면서 겨울철 침식도 심화되는 것으 로 나타났다. 반면 8월에는 평균 파고가 크게 높지는 않았 으나 간헐적인 태풍의 영향으로 침식이 발생하여 해빈폭의 변화가 심했던 것으로 나타났다. 기존의 연구에 따르면 사 건에 대한 해안의 복원은 그 충격이 일시적인지 연속적인 지에 따라 해안에 퇴적과 침식 효과 모두 나타날 수 있지 만, 단독의 극한 사건이 일시적으로 발생할 경우에는 해안 이 평형상태에서 벗어나는 정도가 그 사건의 강도와 기간 에 밀접히 연관되는 것으로 나타났다(Anderson et al., 2010; Splinter et al., 2014; Burvingt et al., 2017). 본 연구에서도 동해안의 해빈폭이 계절의 영향과 더불어 특정 사건의 영향도 크게 받는 것으로 판단된다. 특히 여름과 가 을 사이의 태풍에 의한 집중적인 침식이 해빈폭 변화에 큰 영향을 미치고 있으므로, 이러한 극한 사건의 기간과 강도 에 관한 상세 분석이 필요해 보인다.

- 기간 및 계절에 의한 경향성은 수년 이상의 분석 기간이 확 보될 때 더 명확하게 확인할 수 있을 것으로 기대되므로,
가능한 장기간의 양질의 자료를 확보하는 것이 필요하다. 이를 위하여 품질이 확보된 상태에서 비디오 모니터링을 장 기간 실시할 필요가 있으며, 여기에는 카메라의 설치 상태 나 설치 지점에 대한 보완이 필요할 수 있다. 기술적으로 는 가능한 정제된 영상자료에 대해서 자료처리가 이루어지 도록 하는 등의 방안을 마련할 필요가 있다. 또한 자료의 품질이 현저히 낮거나 양빈 시점이 있는 경우에도 자료를 개선 처리할 수 있는 방법에 대한 연구도 필요하다.

\section{감사의 글}

본 논문은 해양수산부의 "2018년도 연안침식 실태조사" 연 구용역, 그리고 2018년도 정부재원(과학기술정보통신부 여성 과학기술인 R\&D 경력복귀 지원 사업)으로 한국연구재단과 한국여성과학기술인지원센터의 지원을 받아 수행되었습니다.

\section{References}

Anderson, T.R., Frazer, L.N. and Fletcher, C.H. (2010). Transient and persistent shoreline change from a storm. Geophys. Res. Lett. 37.

Burvingt, O., Masselink, G., Russell, P. and Scott, T. (2017). Classification of beach response to extreme storms. Geomorphology, 295, 722-737.

Cho, H.Y., Jeong, S.T., Ko, D.H. and Son, K.-P. (2014). Efficient outlier detection of the water temperature monitoring data. Journal of Korean Society of Coastal and Ocean Engineers 26(5), 285-291 (in Korean).

Cooper, J.A.G. and Pilkey, O.H. (2004). Sea-level rise and shoreline retreat: Time to abandon the Bruun Rule. Glob. Planet. Chang., 43, 157-171.

Davidson, M.A., Splinter, K.D. and Turner, I.L. (2013). A simple equilibrium model for predicting shoreline change. Coast. Eng., 73, 191-202.

Kang, T.S., Nam, S.Y., Kim, M.H. and Baek, K.K. (2007). Study on Characteristics of Coastal Erosion Status Using Real-time Video Monitoring Technique. Magazine of Korean Society of Hazard Mitigation, 7(1), 47-56 (in Korean).

Kang, T.S., Kim, J.B., Kim, G.Y., Kim, J.K. and Hwang, C.S. (2017). Variation Characteristics of Haeundae Beach using Video Image. J. Ocean Eng. Technol., 31(1), 60-68 (in Korean).

Kim, T.R. and Kim, D.S. (2014). Benefits of Camera Monitoring System in Studying on Coastal Dune Erosion by Typhoon. Journal of the Korean Geomorphological Association, 21(4) 41-52 (in Korean).

Kim, T.R. (2016). South/Jeju Coast Beach Erosion Analysis Using Camera Monitoring Data. Journal of the Korean Geomorphological Association, 23(1), 129-140 (in Korean).

Loureiro, C., Ferreira, O. and Cooper, J.A.G. (2012). Geologically constrained morphological variability and boundary effects on embayed beaches. Mar. Geol. 329-331:1-15. 
Masselink, G., Scott, T., Davidson, M., Russell, P. and Conley, D. (2015). The extreme 2013/2014 winter storms: hydrodynamic forcing and coastal response along the southwest coast of England. Earth Surf. Process. Landf. 41, 378-391.

Ministry of Oceans and Fisheries (2015). 2015 Coastal erosion monitoring. 634p (in Korean).

Ministry of Oceans and Fisheries (2016). 2016 Coastal erosion monitoring. 664p (in Korean).

Ministry of Oceans and Fisheries (2017). 2017 Coastal erosion monitoring. $784 \mathrm{p}$ (in Korean).

Ministry of Oceans and Fisheries (2018). 2018 Coastal erosion monitoring. 796p (in Korean).

Múnera, S., Osorio, A.F. and Velásquez, J.D. (2014). Data-based methods and algorithms for the analysis of sandbar behavior with exogenous variables. Comput. Geosci., 72, 134-146.

Pearson, K. (1895). Notes on regression and inheritance in the case of two parents. Proc. R Soc. Lond., 58, 240-242.

Scott, T., Masselink, G., O’Hare, T., Saulter, A., Poate, T., Russell, P., Davidson, M. and Conley, D. (2016). The extreme 2013/
2014 winter storms: beach recovery along the southwest coast of England. Mar. Geol., 382, 224-241.

Splinter, K.D., Carley, J.T., Golshani, A. and Tomlinson, R. (2014). A relationship to describe the cumulative impact of storm clusters on beach erosion. Coast. Eng., 83, 49-55.

Uda, T. (2017). Advanced Series on Ocean Engineering: Volume 43, Japan's Beach Erosion Reality and Future Measures, 2nd Edition.

Wright, L.D. and Short, A.D. (1984). Morphodynamic variability of surf zones and beaches: a synthesis. Mar. Geol., 56(1-4), 93118.

Yates, M.L., Guza, R.T. and O'Reilly, W.C. (2009). Equilibrium shoreline response: Observations and modeling. Geophys. Res., 114.

Received 25 February, 2019

Revised 10 April, 2019

Accepted 18 April, 2019 